\title{
Comparing Maps of Mean Monthly Surface Temperature and Precipitation for Alaska and Adjacent Areas of Canada Produced by Two Different Methods
}

\author{
JAMES J. SIMPSON, ${ }^{1,2}$ GARY L. HUFFORD,${ }^{3}$ CHRISTOPHER DALY, ${ }^{4}$ JARED S. BERG ${ }^{1}$ and MICHAEL D. FLEMING ${ }^{5}$
}

(Received 7 November 2003; accepted in revised form 7 September 2004)

\begin{abstract}
Maps of mean monthly surface temperature and precipitation for Alaska and adjacent areas of Canada, produced by Oregon State University's Spatial Climate Analysis Service (SCAS) and the Alaska Geospatial Data Clearinghouse (AGDC), were analyzed. Because both sets of maps are generally available and in use by the community, there is a need to document differences between the processes and input data sets used by the two groups to produce their respective set of maps and to identify similarities and differences between the two sets of maps and possible reasons for the differences. These differences do not affect the observed large-scale patterns of seasonal and annual variability. Alaska is divided into interior and coastal zones, with consistent but different variability, separated by a transition region. The transition region has high interannual variability but low long-term mean variability. Both data sets support the four major ecosystems and ecosystem transition zone identified in our earlier work. Differences between the two sets of maps do occur, however, on the regional scale; they reflect differences in physiographic domains and in the treatment of these domains by the two groups (AGDC, SCAS). These differences also provide guidance for an improved observational network for Alaska. On the basis of validation with independent in situ data, we conclude that the data set produced by SCAS provides the best spatial coverage of Alaskan long-term mean monthly surface temperature and precipitation currently available.
\end{abstract}

Key words: Arctic hydrology, surface temperature, precipitation, Arctic, climographs, boreal forest, coastal rain forest, Alaska

RÉSUMÉ. On a analysé des cartes représentant les moyennes mensuelles des précipitations et des températures de l'air en surface pour l'Alaska et les zones contiguës du Canada. Ces cartes avaient été établies par le service d'analyse du climat spatial (SCAS) de l'université de l'Oregon et le centre d'échange de données géospatiales de l'Alaska (AGDC). Vu qu'en général le public peut se procurer les deux ensembles de cartes et qu'il les utilise, il est nécessaire de documenter les différences entre les processus et les jeux de données d'entrée utilisés par les deux groupes pour créer leur propre ensemble de cartes, ainsi que de dégager les similarités et les différences entre les deux ensembles de cartes et les raisons possibles de ces différences. Ces dernières n'affectent pas les schémas de variabilité saisonnière et annuelle observés à grande échelle. L'Alaska est divisé en zones intérieures et zones côtières, possédant une variabilité constante mais différente, séparées par une région de transition. Celle-ci possède une grande variabilité interannuelle mais une faible variabilité à long terme de la moyenne. Les deux jeux de données sont compatibles avec les quatre grands écosystèmes et leurs zones de transition que nous avions identifiés dans nos travaux antérieurs. Il y a cependant des différences à l'échelle régionale entre les deux ensembles de cartes; elles témoignent de différences dans les domaines physiographiques et dans le traitement que font les deux groupes (AGDC et SCAS) de ces domaines. Ces différences offrent également une piste pour l'établissement d'un réseau d'observation amélioré pour l'Alaska. En nous basant sur une validation fondée sur des données indépendantes recueillies in situ, nous concluons que le jeu de données produit par SCAS représente actuellement la meilleure couverture spatiale disponible pour les moyennes mensuelles à long terme des précipitations et des températures de l'air en surface en Alaska.

Mots clés: hydrologie arctique, température de l'air en surface, précipitations, Arctique, climogrammes, forêt boréale, forêt pluviale côtière, Alaska

Traduit pour la revue Arctic par Nésida Loyer.

\footnotetext{
${ }^{1}$ Digital Image Analysis Laboratory, Scripps Institution of Oceanography, La Jolla, California 92093-0237, U.S.A.

${ }^{2}$ Corresponding author: jsimpson@ucsd.edu

${ }^{3}$ U.S. National Weather Service, Federal Building, 222 West 7th Street, Anchorage, Alaska 99513-7504, U.S.A.

${ }^{4}$ Spatial Climate Analysis Service, Department of Geosciences, 326 Strand Agricultural Hall, Oregon State University, Corvallis, Oregon 97331-2204, U.S.A.

${ }^{5}$ Raytheon at USGS/EROS Field Office, 4230 University Drive, Suite 230, Anchorage, Alaska 99508-4664, U.S.A.

(C) The Arctic Institute of North America
} 


\section{INTRODUCTION}

Global climate models (IPCC, 1996) and data (Karl et al., 1993) indicate increases in Arctic precipitation and temperature, which have been attributed to increasing concentrations of greenhouse gases. Considerable uncertainty, however, exists in Arctic precipitation estimates. The very sparse precipitation gauge network in Alaska, for example, suffers from the same systematic errors and inhomogeneities in precipitation measurements observed elsewhere (Sevruk, 1982). Such inhomogeneities, however, are especially severe in Alaska. Bias corrections require extensive site data that typically are not available. As an indication of error, Legates and Wilmot (1990) found mean annual bias errors of well over $15 \%$ in the Rocky Mountains. For these and other reasons, observational estimates based on gauge-adjusted station data-corrected for a variety of problems related to bucket collection devices, e.g., horizontal wind - are considerably larger than other observational estimates (Walsh et al., 1998).

Mean monthly maps of Alaskan surface temperature and precipitation produced by Oregon State University's Spatial Climate Analysis Service (SCAS) were recently analyzed by Simpson et al. (2002). On the basis of this analysis, they divided Alaska into interior and coastal zones with consistent but different climatic variability separated by a transition region, which has high interannual variability but low long-term variability. Events like the El Niño Southern Oscillation (ENSO) and the Pacific Decadal Oscillation (PDO) were found to influence statewide Alaskan surface temperature weakly $\left(1-2^{\circ} \mathrm{C}\right)$. PDO has a stronger influence than ENSO on precipitation, but its influence is largely limited to coastal central Alaska. Precipitation in northern and interior Alaska (and adjacent areas of Canada) is influenced by the Arctic Oscillation (AO). Four major ecosystems were defined, and a major eco-transition zone was identified between the interior boreal forest and the coastal rainforest. Variability in insolation, surface temperature, precipitation, continentality, and seasonal changes in storm track direction help to explain the mapped ecosystems. Lack of expansion of the interior boreal forest into the western shrub tundra is influenced by the coastal marine boundary layer (enhanced cloud cover, reduced insolation, and cooler surface and soil temperatures). In this context, it was hypothesized that the action of the marine boundary layer is analogous to that of the orographic features that form the natural boundaries of the other Alaskan ecosystems identified (see Simpson et al., 2002 for details).

We examined mean monthly temperature and precipitation maps of Alaska made by two different groups: the Alaska Geospatial Data Clearinghouse (AGDC) and the Oregon State University's Spatial Climate Analysis Service (SCAS). Because both the AGDC and SCAS have recently made their maps available to the community, it is important to document the differences between the two processes (including input data sets, interpolation meth- ods, expert knowledge, and quality control) that they used to produce their respective sets of Alaskan maps. We assessed the similarity of the two sets of maps, extracting patterns of spatial and temporal variability in surface temperature and precipitation common to both modeled data sets, and related these patterns to Alaskan regional ecosystems. We considered the differences between the two data sets in relation to physiographic regions and their respective treatments by the AGDC and SCAS groups. On the basis of these analyses, we suggest some improvements for the surface observational network in Alaska.

Alaska is often divided into five separate geographical regions (Fig. 1a), designated as southeast, south-central, southwest, interior and the far North. Figure 1 also provides a reference map for place-names used in the text. The locations and topography of the mountain ranges and other geographic features cited are given in Figure 2. Throughout the text, the terms Australian National University Spline Interpolator (ANUSPLIN), used by AGDC, and the Parameter-elevation Regression on Independent Slopes Model (PRISM), used by SCAS, only indicate a specific modeling/interpolation method. The data sets produced by the AGDC and SCAS groups are referred to as the AGDC data set and the SCAS data set, respectively.

\section{BACKGROUND}

The production of a spatial climate analysis is a semiempirical process driven by a number of factors, which stem from the background of the analysis group, the tools available to that group, the intended use of the analysis upon completion, and the numerous decisions, many subjective, that are made along the way. Specifically, some of these factors include collection and quality control of station data; selection, modification, and parameterization of an interpolation method; availability of expert knowledge for the creation of the analyses; and use of external peer review of draft versions of maps. The complexity of this process makes it difficult, if not impossible, to compare different spatial climate analyses of a given region in a fully objective, quantitative way. Much insight can be gained, however, by understanding the conditions and motivations behind each analysis.

The AGDC and SCAS Alaskan climate analyses were created by groups with different areas of expertise, whose motivations and intended uses for the data were different; hence it is no surprise that different methods were used. Background information for each analysis is presented below to provide a context for comparison.

\section{AGDC Analysis}

The AGDC serves as the main source of geospatial data for the state of Alaska and provides a variety of spatial data sets for assessment of ecological processes and resource management. The AGDC Alaska climate analysis was 


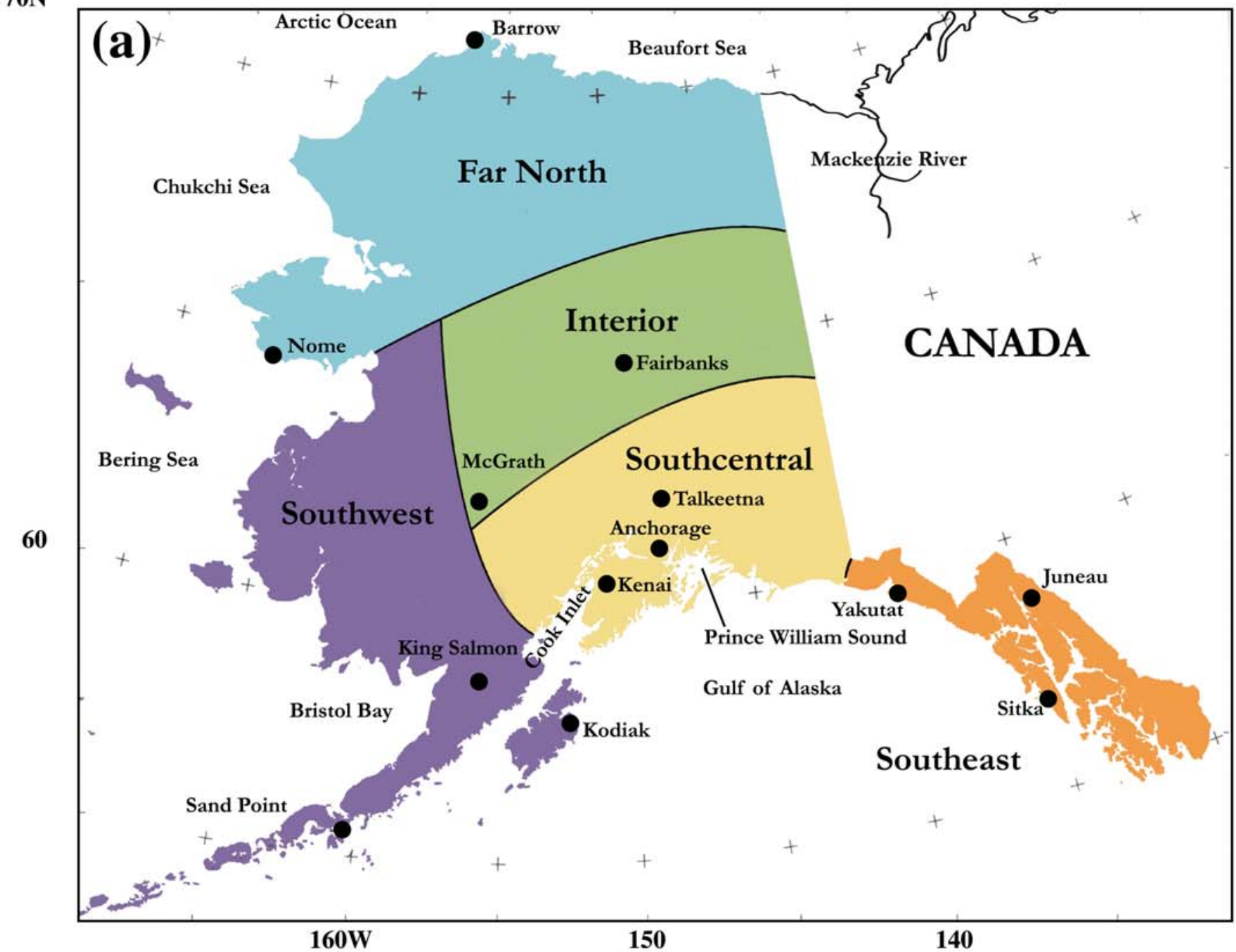

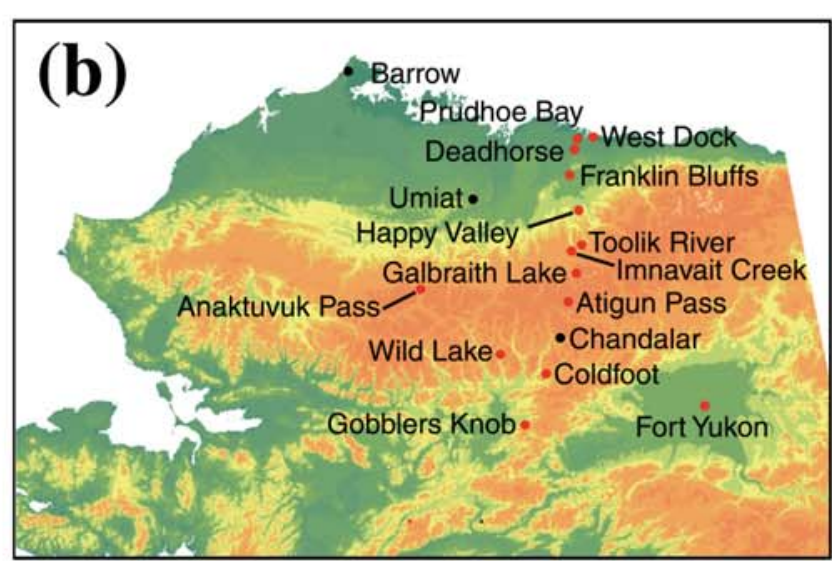

Detail of Arctic Coast, Arctic Inland, Arctic Foothills, Brooks Range and Interior Foothills

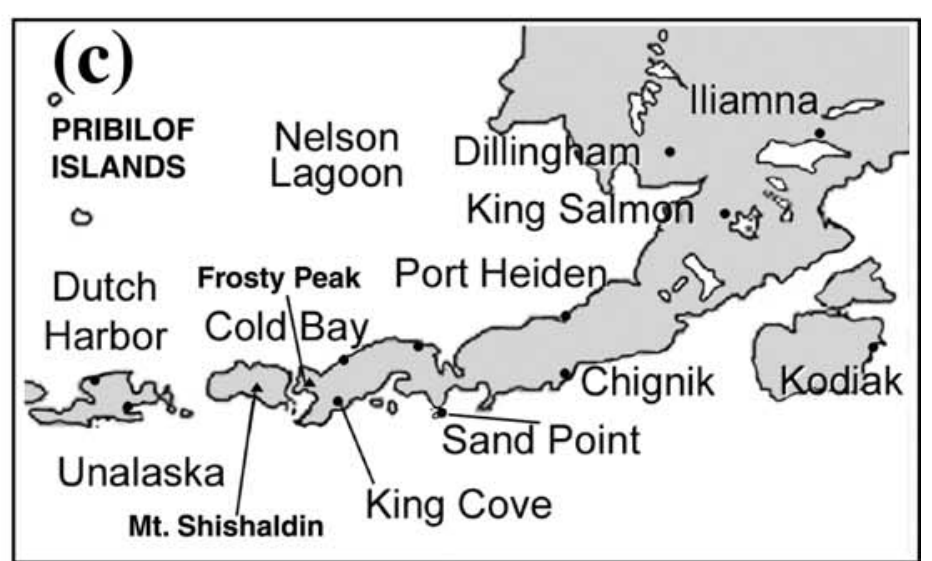

Detail of Alaskan Peninsula and Upper Aleutian Islands

$$
\text { LEGEND for panels (b) and (c): • Cities } \quad \bullet \text { Data Sites } \Delta \text { Volcanoes }
$$

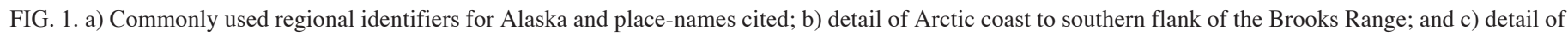
a section of the Alaskan Peninsula and Aleutian Islands. 


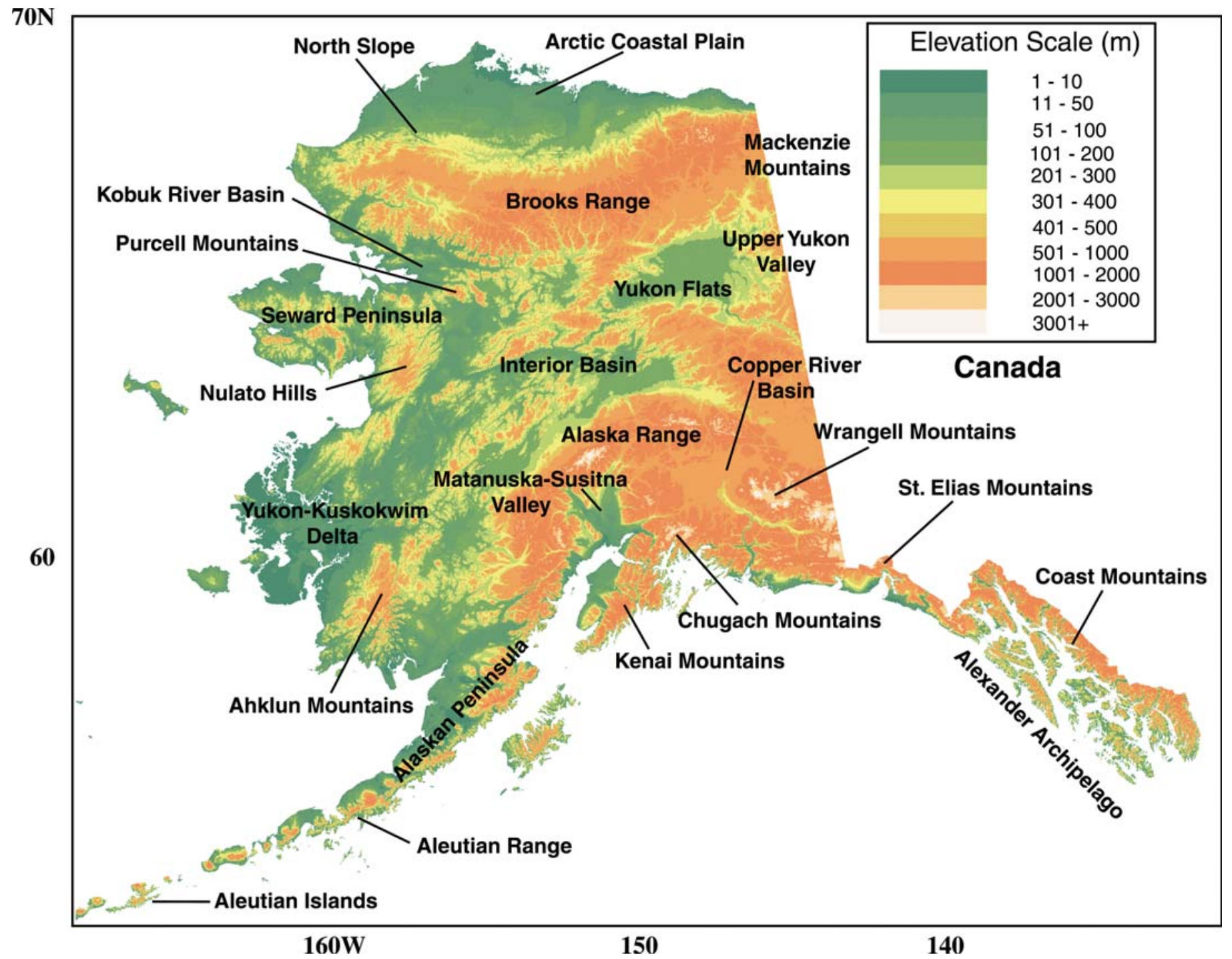

FIG. 2. Location and topography of mountain ranges and other geographical features cited.

created to provide an important climatic component to the data sets, thus allowing a better understanding of the distribution of vegetation from a climatic standpoint and serving as input to models of ecosystem function.

The purview of the AGDC extends far beyond climate into many other types of geospatial data, including transportation, hydrography, geology, ecosystem units, and administrative units; there is no particular focus on geospatial climatology. The AGDC climate analysis made use of readily available station data sets and a freely available interpolation method. Only a cursory external review was performed on the draft maps.

\section{SCAS Analysis}

SCAS, as one of the few institutes in the world dedicated solely to the spatial analysis of climate, is deeply involved in the advancement of geospatial climatology as a discipline. The SCAS Alaska climate analysis is part of a larger U.S. Department of Agriculture (USDA) Natural
Resources Conservation Service (NRCS) Water and Climate Center project with SCAS to produce peer-reviewed maps of major climatic elements for the United States and its possessions (USDA-NRCS, 1998; Daly et al., 2001). The chief function of this project is to produce the official base climate layers that the USDA requires to administer its multitude of climate-related projects. These maps must be accurate and detailed enough to be suitable for use by field offices, decision makers, and scientists.

The final maps for each state were the result of rigorous and repeated internal and external peer reviewing of draft analyses, a process that spanned several years. SCAS sees these reviews as a critical part of the process because observed climate data are very sparse or unavailable in many remote mountainous regions. Experts are needed to provide skillful assessments based on a thorough meteorological knowledge of a given region, synthesized with information from sources such as short-term intensive observations, vegetation maps, satellite imagery, and streamflow data. 
TABLE 1. Features of the ANUSPLIN and PRISM Interpolation Models. See text for details.

\begin{tabular}{|c|c|c|}
\hline Feature & ANUSPLIN & PRISM \\
\hline 1. Assumes elevation is single most important variable determining surface temperature and precipitation. & Yes & Yes \\
\hline 2. Uses three-dimensional interpolation methods. & Yes & Yes \\
\hline 3. Provides a method for incorporating/weighting other variables into the interpolation scheme. & No & Yes \\
\hline 4. Can differentiate station data with windward and leeward exposures. & No & Yes \\
\hline 5. Incorporates a two-layer atmosphere (boundary layer, free layer) into the interpolation scheme. & No & Yes \\
\hline 6. Can identify inversion layers. & No & Yes \\
\hline 7. Uses trajectory model to help determine wet from dry regions in coastal areas. & No & Yes \\
\hline 8. Uses a coastal proximity grid to help establish station weighting in the interpolation. & No & Yes \\
\hline 9. Uses "facet" concept in the interpolation to help identify sharply defined climate regimes delineated by terrain features. & No & Yes \\
\hline 10. Extends model domain beyond coastline to include near-shore area. & No & Yes \\
\hline
\end{tabular}

Many aspects of the SCAS Alaska climate analysis have been improved through the review process. The results include a better and more extensive selection of station data, use of satellite imagery to gain knowledge of temperature inversions, improvement of the interpolation method to recognize and correct misleading climateelevation relationships produced by sparse data, and development of storm trajectory and coastal proximity models. These efforts are discussed later in this paper. The USDA NRCS climate mapping project is ongoing and will continue to improve its climate analyses in the coming years. Feedback from users of the current analyses will play a key role in future mapping efforts.

\section{INTERPOLATION METHODS USED BY THE AGDC AND SCAS GROUPS}

\section{The Australian National University Spline Interpolator (ANUSPLIN)}

Local interpolation, using a nearest-neighbor approach, gives interpolated values that do not, in general, have continuous first or second derivatives (Johnson and Reiss, 1982). Spline-based interpolation methods circumvent this problem. A spline is a polynomial between each pair of table points (e.g., location, surface temperature observation) but whose coefficients are determined in a "slightly" non-local fashion. The non-local nature of the fit is designed to ensure global smoothness of the interpolated function up to some order of derivative. The ANUSPLIN interpolator (Hutchinson, 1995) uses thin-plate smoothing splines because this method of interpolation has been shown suitable for interpolating sparse data networks across large regions with topographical diversity (Wahba, 1979; Cramer and Leemans, 1993). Mathematical details of the interpolation process are given in the references cited.

ANUSPLIN makes the assumption that most climate variables show strong variation with elevation. Because this variation often is non-linear and its rate is locationdependent, simple scaling by altitude (e.g., adiabatic lapse rate) is generally inappropriate. ANUSPLIN addresses this issue by using elevation as a third variable in the spline interpolation. The resulting surfaces (e.g., smoothed maps of precipitation) are defined in terms of all three spatial coordinates. This allows regional climate variations associated with latitude and continentality to be taken into account simultaneously with elevation and rain shadow effects, provided that these are captured sufficiently by the station network (Fleming et al., 2000). ANUSPLIN was used by the AGDC group to make its Alaskan climate maps.

\section{The Parameter-Elevation Regression on Independent Slopes Model (PRISM)}

The PRISM model (Daly et al., 1994, 2001, 2002) assumes that for a localized region, elevation $(\mathrm{Z})$ is the most important factor in the distribution of temperature $(\mathrm{T})$ and precipitation $(\mathrm{P})$. The effects of other variables are controlled by assigning to data from each station a combined weight, which is a function of distance, elevation, cluster, vertical layer, topographic facet, coastal proximity, and effective terrain. "Facets" are used to identify sharply defined climate regimes delineated by terrain features (e.g., rain shadows); this prevents mixing data from stations with windward and leeward exposures (Gibson et al., 1997). PRISM also assesses the orographic effectiveness of topographic features that are sharply defined (moisture blocking) and those that slope gently. To simulate abrupt climatic shifts with elevation (e.g., shallow orographic precipitation and temperature inversions), PRISM divides the climate stations used in the local regression into two layers. Layer 1 represents the boundary layer, and layer 2 , the free atmosphere above it. The thickness of the boundary layer can be changed to reflect a marine boundary layer or a temperature inversion. Inversions are determined from available surface station data and the Global Gridded Upper Air Statistics data set (Kållberg et al., 2004). For Alaskan precipitation, a simple trajectory model that moves moist air parcels over complex terrain in coastal areas is used to determine relatively wet and dry areas for station weighting. For Alaskan temperature, an advection model that tracks maritime air penetration into the coastal terrain is used to produce a coastal proximity grid; PRISM weights stations according to their similarity in coastal proximity to the target grid 


\section{ANUSPLIN}
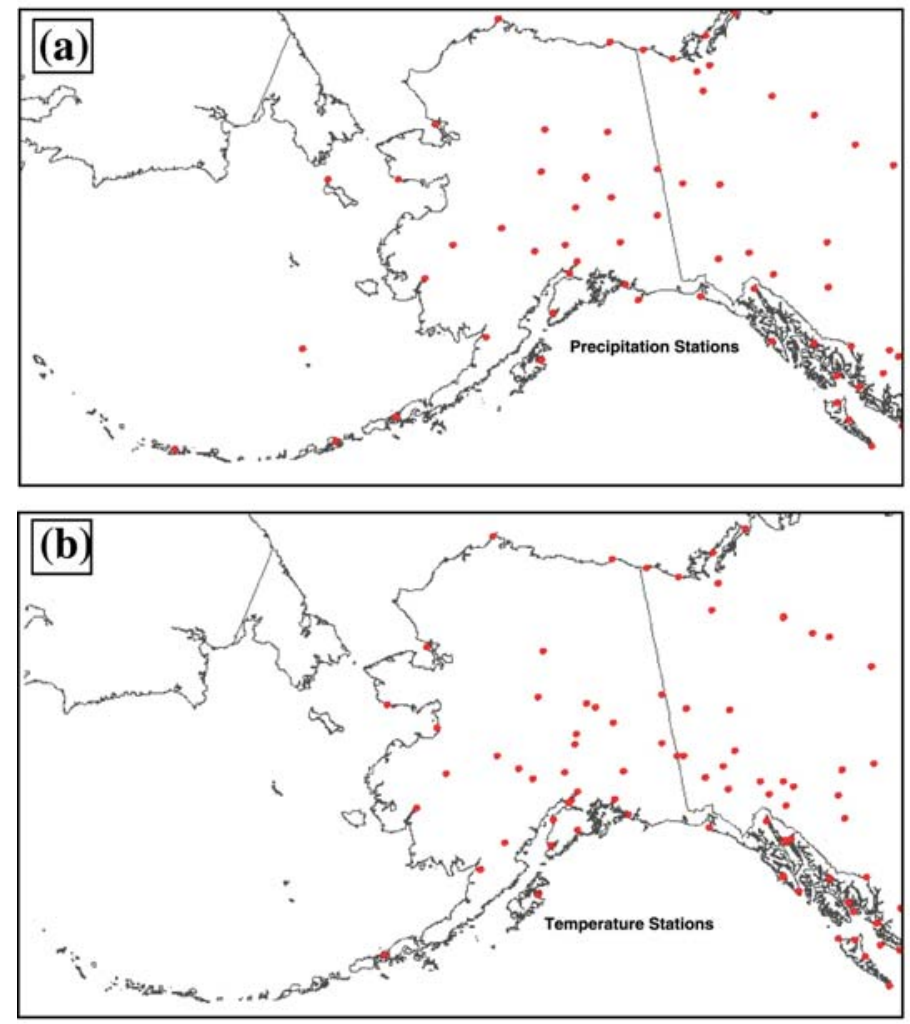

PRISM
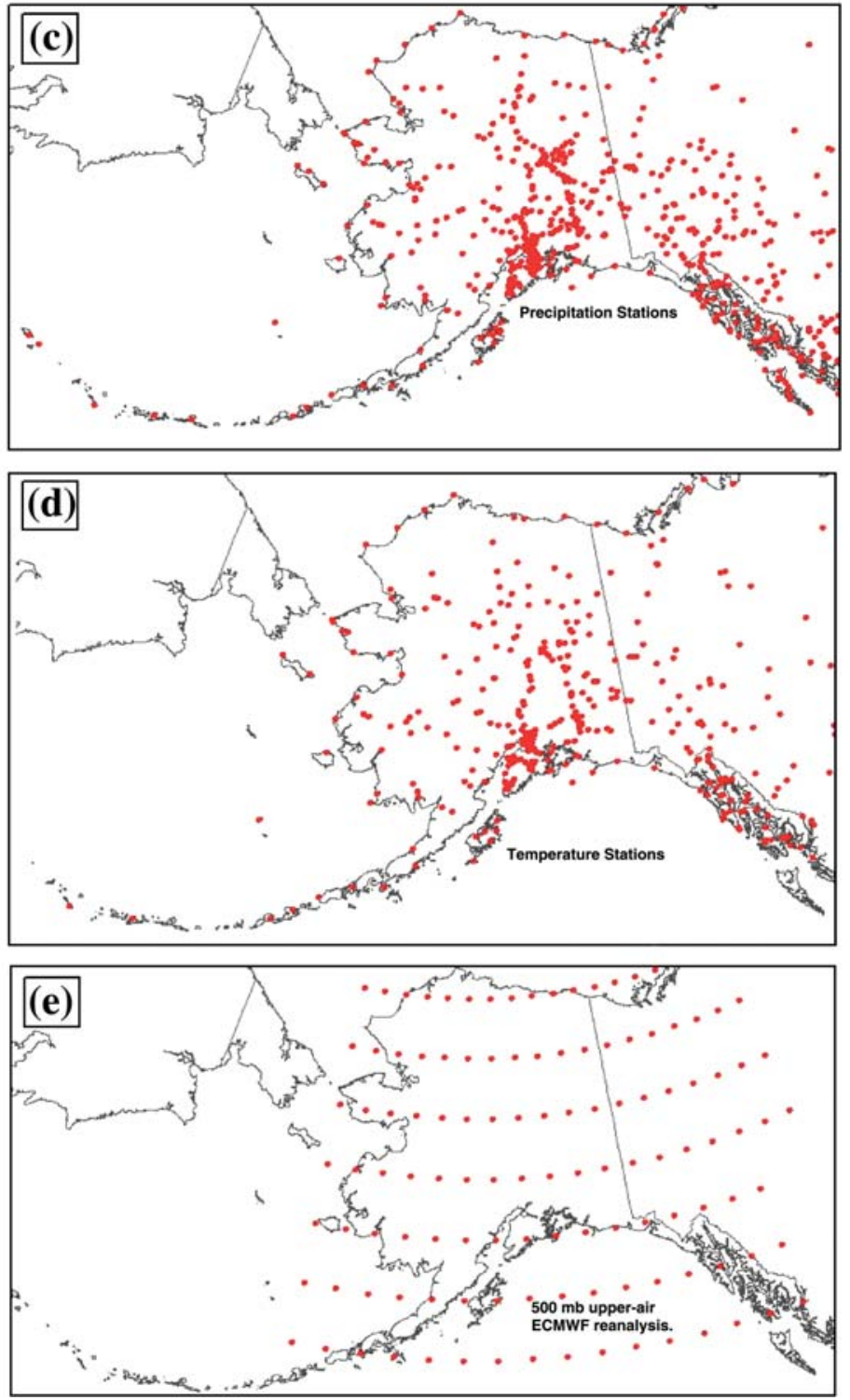

FIG. 3. Input station data grids used by the ANUSPLIN and PRISM interpolators.

cell. The aspect ratio of the terrain determines the mapping approach (method of interpolation between target grid cells). Generally, a three-dimensional approach is used (see Daly et al., 1994, 2001, 2002, 2003 for details and Simpson et al., 2002 for Alaska specifically). PRISM was used by the SCAS group to make its Alaskan climate maps.

\section{Major Differences between ANUSPLIN and PRISM}

The PRISM and ANUSPLIN models are fundamentally different (Table 1). PRISM, for example, uses a two-layer atmosphere to model the effects of atmospheric inversions on surface temperature. ANUSPLIN cannot. The ANUSPLIN and PRISM model grids are also somewhat different along coastlines. The PRISM analysis typically extends beyond the coastline to include nearshore areas, while the ANUSPLIN analysis is largely restricted to land areas. This variation in model treatment of Alaskan coastlines has no significant impact on results. When an analysis on a specific data set (AGDC or SCAS) is performed, then the full grid of that data set is used. When an intercomparison analysis between modeled data sets is performed (e.g., AGDC - SCAS), only pixels common to both data sets are used.

\section{INPUT DATA USED BY THE ANUSPLIN AND PRISM MODELS}

\section{Input Data for ANUSPLIN}

The National Climatic Data Center (NCDC) produced a quality-controlled global historical climatology network (GHCN) of long-term monthly surface temperature and 
TABLE 2. Input data (precipitation and temperature) used by ANUSPLIN and PRISM as indicated. All acronyms are defined in the text; see text for details.

\begin{tabular}{llc}
\hline \hline Data & ANUSPLIN & PRISM \\
\hline $\begin{array}{l}\text { Precipitation: } \\
\text { 54 GHCN precipitation records }\end{array}$ & \\
283 NWS COOP observing stations & Yes & Yes $^{1}$ \\
44 USDA/NCRS Snotel stations & No & Yes \\
128 USDA snow course stations & No & Yes \\
41 precipitation stations from Yukon and BC & No & Yes \\
$\quad$ from Environment Canada) & No & Yes \\
48 snow course stations from the Yukon and BC & & \\
$\quad$ from Environment Canada) & No & Yes \\
Digital Elevation Model & Yes & Yes \\
& & \\
Temperature: & & \\
74 GHCN station records & Yes & Yes \\
278 NWS COOP station records & No & Yes \\
10 Snotel station records & No & Yes \\
28 BLM/Forest Service RAWS station records & No & Yes \\
500 mb reanalysis temperature data & No & Yes \\
Radiosonde data & No & Yes \\
Digital Elevation Model & Yes & Yes \\
\hline \hline
\end{tabular}

${ }^{1}$ In the PRISM mapping, GHCN precipitation data were replaced when possible with shielded Snotel data to minimize the effects of undercatch associated with unshielded GHCN precipitation gauges.

precipitation (Vose et al., 1992). Fifty-four precipitation and 74 temperature records for Alaska and adjacent areas of Canada are available in the GHCN (Fig. 3a, b, Table 2). The average length of each record is about 60 years, but lengths range from 10 to 159 years. Only three stations have short (10 year) records, and all these stations are located on Alaska's North Slope. ANUSPLIN used all GHCN data; most stations include the period from 1930 (or earlier) to 1990.

The GHCN precipitation gauges, like all gauges in the American observing system, measure total liquid precipitation (rain plus melted frozen precipitation). The vast majority of GHCN precipitation gauges in Alaska are unshielded. This results in significant undercatch, especially for snowfall at high wind speeds. Comparison between Wyoming shielded gauges and standard National Weather Service (NWS) eight-inch unshielded gauges shows that the unshielded gauges underestimate precipitation in Alaska by $75 \%$ on average, with a range of $20 \%$ to $180 \%$ (Zhang et al., 1996). Additional studies of undercatch in Alaska (Benning et al., 2002) are consistent with the earlier work of Zhang et al. (1996). Spatial patterns of precipitation obtained from the two measuring systems, however, are well correlated. No corrections for undercatch were made to the GHCN precipitation data for the ANUSPLIN interpolation.

ANUSPLIN also uses the elevation grid for Alaska $(15 \times 15$ arcseconds but resampled to $30 \times 60$ arcseconds $)$ of the Earth Resource Observations Systems (EROS) Data Center, United States Geological Survey (USGS), as an input to its thin plate smoothing spline interpolator.

\section{Input Data for PRISM}

PRISM uses a larger data set, which is spatially denser than that used by ANUSPLIN. It consists of 455 Alaskan stations (Fig. 3c, Table 2) for precipitation, 283 NWS Cooperative (COOP) observing stations, 44 USDA-NCRS Snotel stations, and 128 USDA snow course stations. During the PRISM modeling process, comparisons of shielded Snotel gauge data to unshielded GHCN gauges on Alaska's North Slope showed undercatch by the unshielded gauges of about $100 \%$ during the winter months, a finding consistent with earlier studies (Larsen and Peck, 1974; Goodison et al., 1981; Zhang et al., 1996; Yang et al., 1998, 2000). To minimize such effects, shielded Snotel gauge data were used preferentially over NWS unshielded gauge data whenever possible. In addition, data obtained from Environment Canada for 41 precipitation and 48 snow course stations in the Yukon and British Columbia were included in the analysis. Since data from the Yukon and the northern half of British Columbia were raw monthly values, they were aggregated into longer-term means prior to use in the PRISM model. Data for the southern half of British Columbia were standardized to the climatological period 1961-90 (Hourston, 1998). The influence of data from southern British Columbia on the SCAS Alaskan maps was small and generally confined to the southern part of the Alaskan Panhandle.

Surface temperature was modeled using data from 316 Alaskan stations (Fig. 3d, Table 2); 278 NWS COOP stations, 10 Snotel stations, and 28 Bureau of Land Management/U.S. Forest Service Remote Automated Weather Station (RAWS) stations. The European Center for Medium-range Weather Forecasts' (ECMWF) reanalysis of temperatures at the $500 \mathrm{mb}$ height, with a spatial resolution of 2.5 degrees of latitude and longitude (Fig. 3e), was also used. The PRISM input data set covers a 30-year climatological normal period (1960-90), but does include some stations with shorter periods of record.

PRISM also uses a digital elevation model (DEM) to generate gridded estimates of climate parameters, namely the Global 30-arcsecond elevation grid (GTOPO30) of the EROS Data Center, USGS (Daly et al., 1994, 2002, 2003). Prior to the modeling, the 30 -arcsecond DEM values were low-pass filtered to 2.5 minute spatial resolution.

\section{RESULTS}

The AGDC data set comprises maps of mean monthly surface temperature $\left({ }^{\circ} \mathrm{C}\right)$ and precipitation $(\mathrm{mm})$ with corresponding range maps. The SCAS maps of mean monthly surface temperature $\left({ }^{\circ} \mathrm{C}\right)$ were computed by averaging maximum and minimum mean temperatures for a given month. Both the AGDC and SCAS data sets were remapped to a common Alaska standard Albers equal area projection with $1 \mathrm{~km}$ resolution to facilitate intercomparisons. 
We noted differences and similarities between AGDC and SCAS mean monthly surface temperature and precipitation maps and used Empirical Orthogonal Functions (EOFs) to extract spatial patterns that define regions in Alaska with similar seasonal characteristics. The temporal amplitudes associated with the EOFs helped to identify the seasons when the extracted patterns of spatial variability dominated the data. This information helps to identify transition zones between different regimes in Alaska. We also used selected climographs to show the sensitivity of species-specific ranges to modeled differences of mean monthly temperature and precipitation.

\section{Temporal and Spatial Means}

Mean monthly maps (January, April, July, and October) of Alaskan surface temperature for the AGDC data set (Fig. 4a, e, i, m) and the SCAS data set (Fig. 4b, f, j, n) show similar spatial structure. Corresponding difference (AGDC - SCAS) maps (Fig. 4d, h, l, p) and their histograms (Fig. 4c, g, k, o) show that these differences are relatively small for most pixels. Agreement (to $\pm 2^{\circ} \mathrm{C}$ ) between the two sets of maps is best in July and worst in January. In this and all subsequent figures in which black is overlaid on color, first the analysis was performed on all pixels in the data set(s), and then the black overlay was applied. The range of values associated with the black overlay for a given figure is indicated in that figure. Generally, the black overlay is used to indicate a region of small values in a given data set or a region of small differences between data sets for a given variable. Note that the color key for a given figure may contain color cells that span a set of values partially within and partially outside that figure's black overlay range.

Analogous precipitation maps (Fig. 5) also show similar large-scale spatial structure. The dynamic ranges of the two data sets, however, are significantly different. Thus, in selected regions (e.g., southeast Alaska), the SCAS data set shows climate to be much wetter than the AGDC data set. The effects of isolated data values (e.g., the bull's-eye pattern) are more prevalent and pronounced in the precipitation maps than in the temperature maps. Moreover, the AGDC maps are more significantly affected by such values than the corresponding SCAS maps.

Histograms of the precipitation differences show that the AGDC and SCAS data sets agree (to $\pm 20 \mathrm{~mm}$ ) for the majority of pixels. Agreement is best in April and worst in October. In general, histograms of the surface temperature differences (Fig. 4c, g, k, o) better approximate a normal distribution than those of precipitation (Fig. 5c, g, k, o). Differences in precipitation are dominated by extrema more often than those of temperature.

Maximum seasonal differences (mean January-mean July) in surface temperature occur in central Alaska and adjacent areas of Canada, while minimum seasonal differences occur in southeast Alaska, in a narrow coastal region around much of the state, and throughout the Aleutian
Islands (Fig. 6a, b). For precipitation, positive seasonal differences occur in southeast Alaska (Fig. 6c, d). The coasts of south-central Alaska and the Aleutian Islands (especially the outer islands) also have some positive seasonal differences, but these are generally smaller than those in southeast Alaska. Maximum negative differences occur in some northern portions of south-central Alaska, in interior Alaska, and in adjacent areas of Canada. This annual variation is determined by the seasonal cooling and warming of the interior while coastal variability is moderated by the oceans. Again, the black overlay in Figure 6 was applied after the differencing between modeled data sets was performed.

The AGDC - SCAS difference of their respective mean January-July seasonal difference maps (Fig. 6a, 6b) shows regions of Alaska where the two data sets disagree most in the magnitude of seasonal variation in surface temperature (Fig. 7a). These regions occur in central Alaska and adjacent areas of Canada (where the AGDC seasonal temperature differences are largest) and along parts of the North Slope (where the SCAS seasonal differences are largest). The corresponding map for precipitation seasonal difference (Fig. 7b) shows that both data sets correctly indicate that July is wetter than January for most regions of Alaska, except for the coastal regions of south-central Alaska, southeast Alaska, and parts of the Aleutian Islands, where the reverse is true. This seasonal difference generally is larger for the SCAS data set (e.g., southeastern coastal Alaska, central Alaska, adjacent areas of Canada) than for the AGDC data set. Again, the differencing was performed on the full set of data before the black overlay was applied.

Annual (12 month) mean monthly surface temperatures $\left({ }^{\circ} \mathrm{C}\right)$ were computed for the AGDC and the SCAS data sets (Fig. 8a, b). Maxima occur in the coastal regions of southeastern and south-central Alaska, the Alaska Peninsula and along the Aleutian Islands. Minima occur in the mountains (Alaska Range, Chugach Mountains, and Wrangell-St. Elias Mountains) of south-central Alaska, northern Alaska (Brooks Range and North Slope), and adjacent areas of Canada. Mean monthly statewide temperatures at each time step (Fig. 8c) show an annual cycle with a high in July and a low in January. Monthly mean temperature differences (AGDC - SCAS) are relatively small compared to the dynamic range of Alaskan surface temperatures (Fig. 8d).

Annual (12 month) mean monthly precipitation (Fig. 8e, f) is maximum in the coastal regions of southeast and south-central Alaska and along the Aleutian Islands. Minima occur in the central interior region of Alaska, north of the Brooks Range, and in adjacent areas of Canada. Precipitation also has a well-developed seasonal cycle (Fig. 8g), but it is out of phase with that of temperature. The AGDC data set shows a maximum in August, not July, and a minimum in April, not January, and the SCAS data set shows an extended maximum from August to October. Again, the mean monthly precipitation differences (AGDC - SCAS) generally are relatively small compared to the 

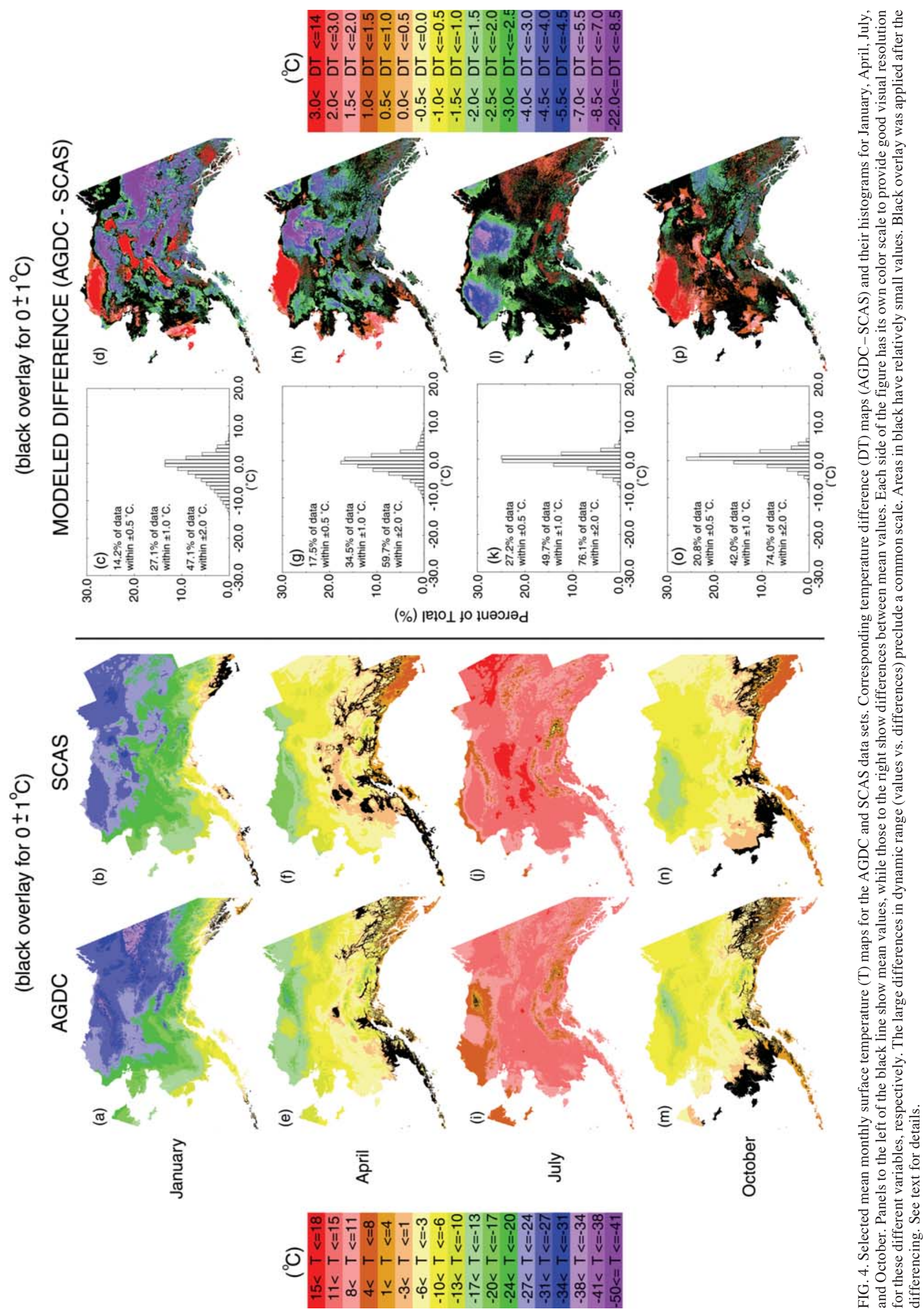


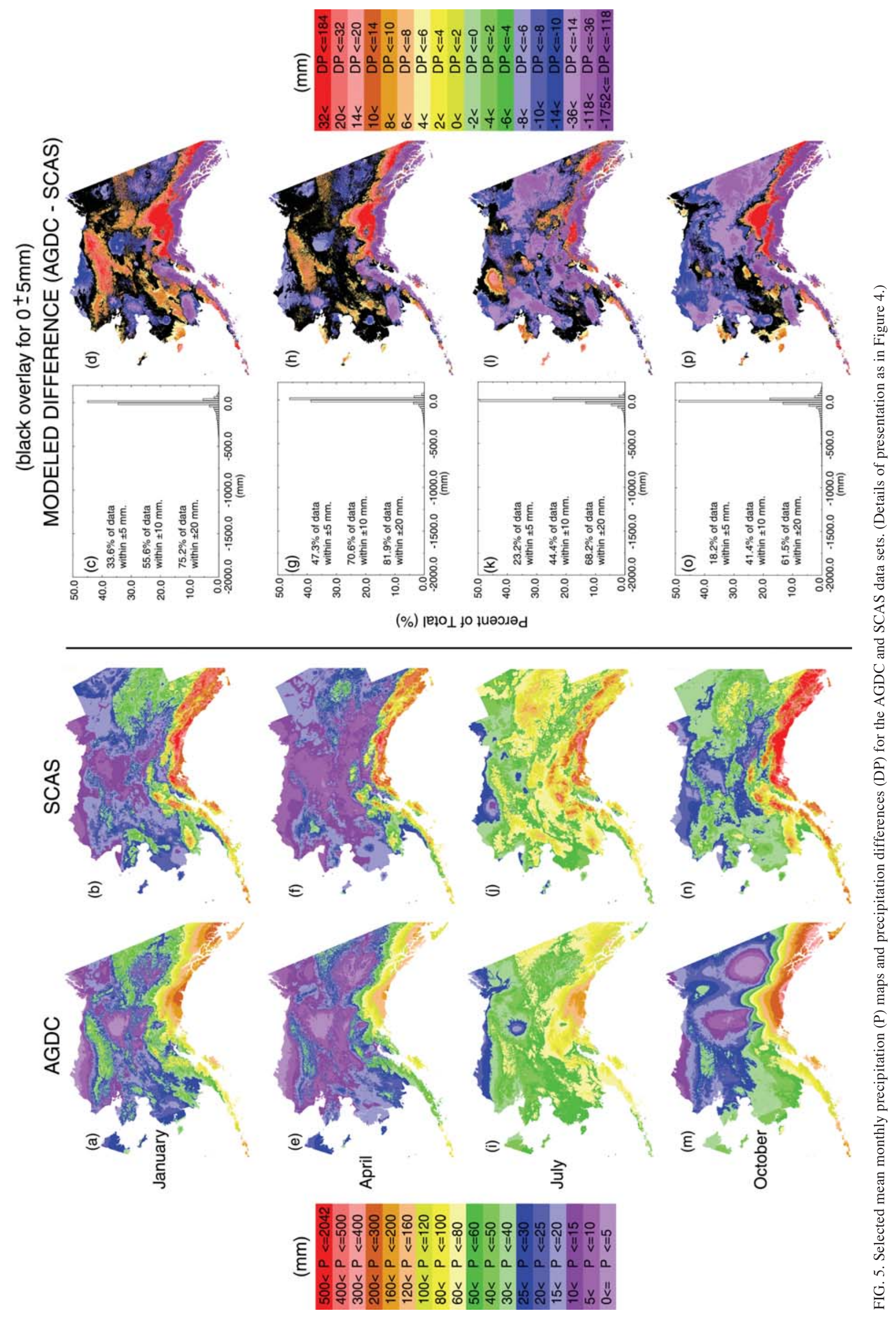




\section{Temperature}

\section{Precipitation}

\section{AGDC}

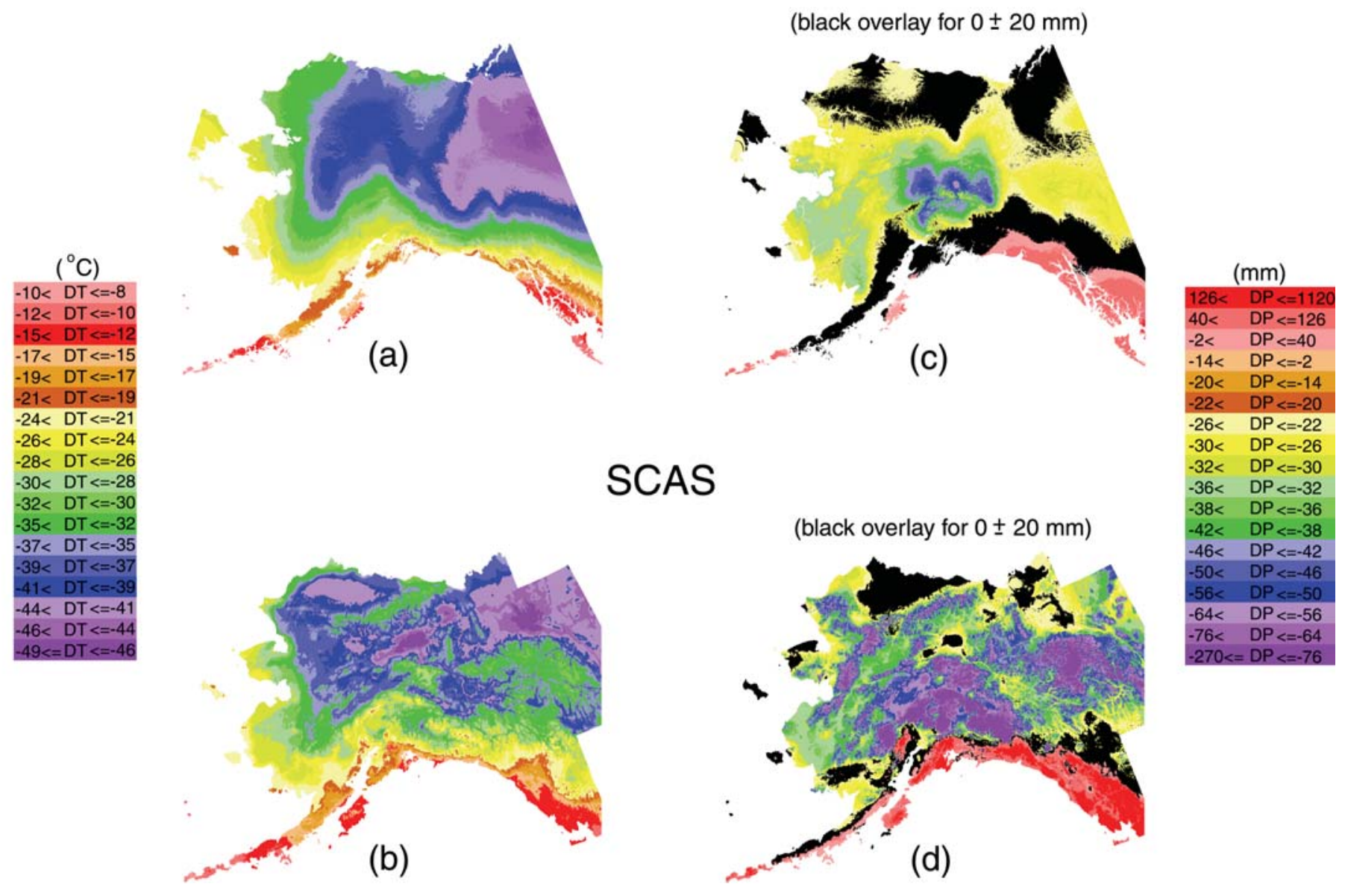

FIG. 6. Seasonal difference (January-July) for temperature (a, b) and precipitation (c, d) for the AGDC and SCAS data sets. The black overlay, applied after the differences were computed, indicates areas in Alaska where the seasonal differences are relatively small. Color keys give ranges of differences, DT for temperature and DP for precipitation.
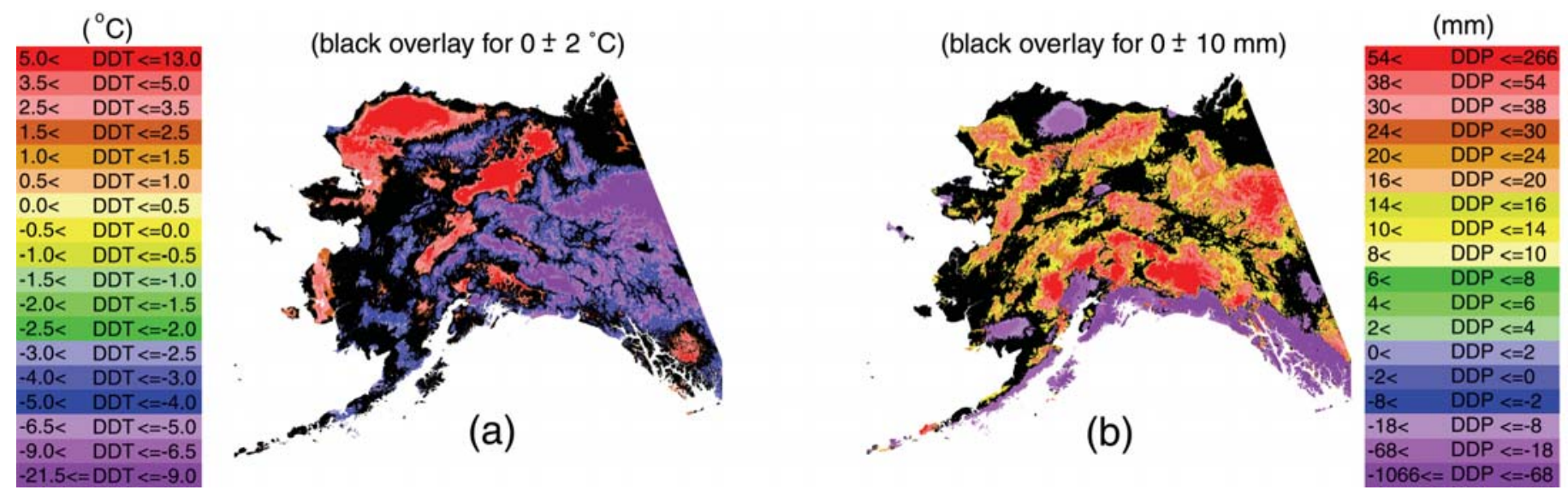

FIG. 7. Differences between the mean seasonal differences (Fig. 6) modeled by the AGDC and the SCAS data sets for a) temperature and b) precipitation. DDT and DDP color keys are analogous to those in Figure 6.

dynamic range of Alaskan precipitation (Fig. 8h). Note that the data in Figure 8e and $\mathrm{f}$ are not mean annual totals, but rather the mean monthly values averaged over the 12 months of a year. When multiplied by 12 , they give an approximate mean annual total precipitation at a given location. 
$148 \bullet$ J.J. SIMPSON et al.

AGDC

$\left({ }^{\circ} \mathrm{C}\right)$
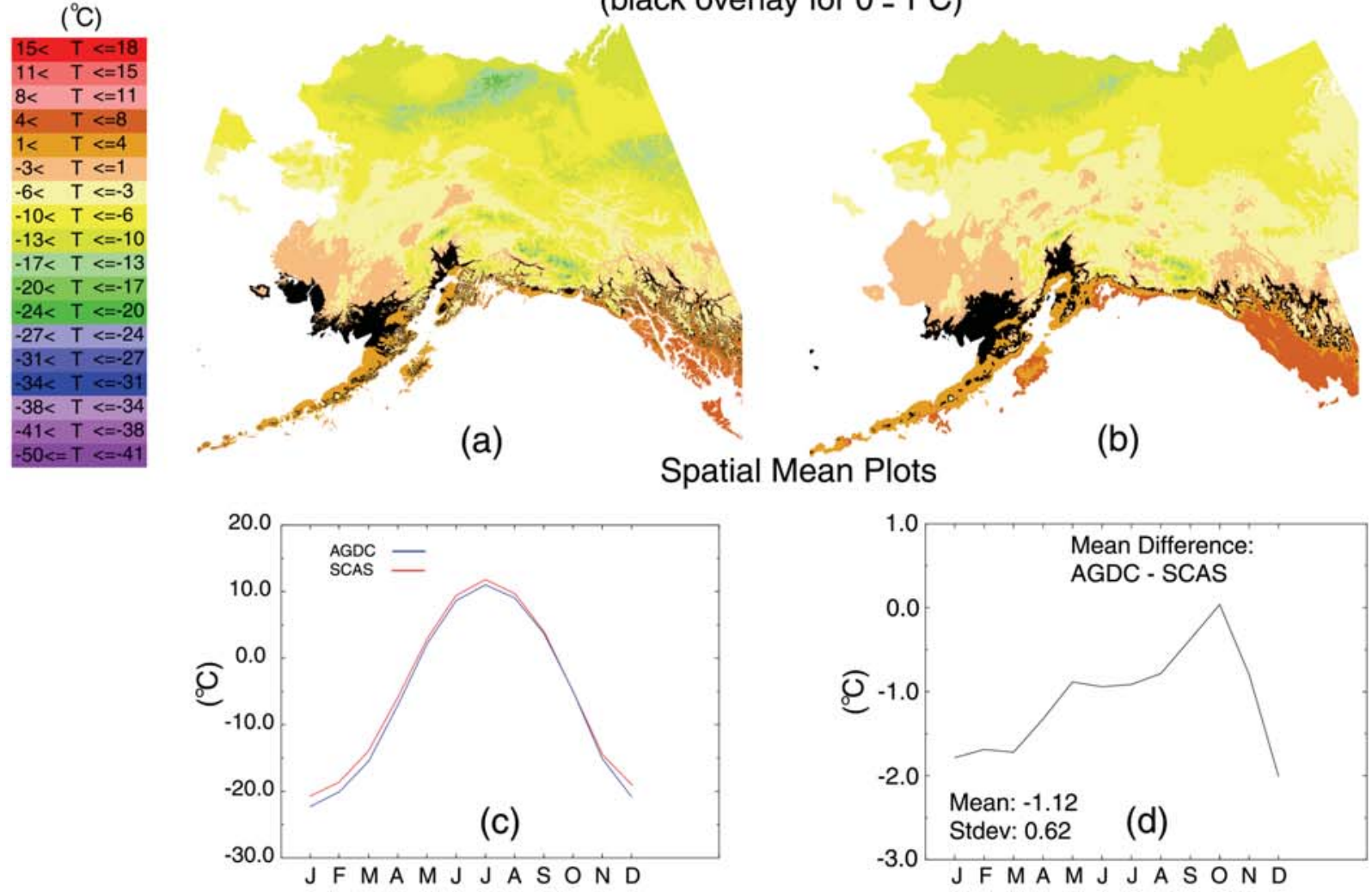

Month
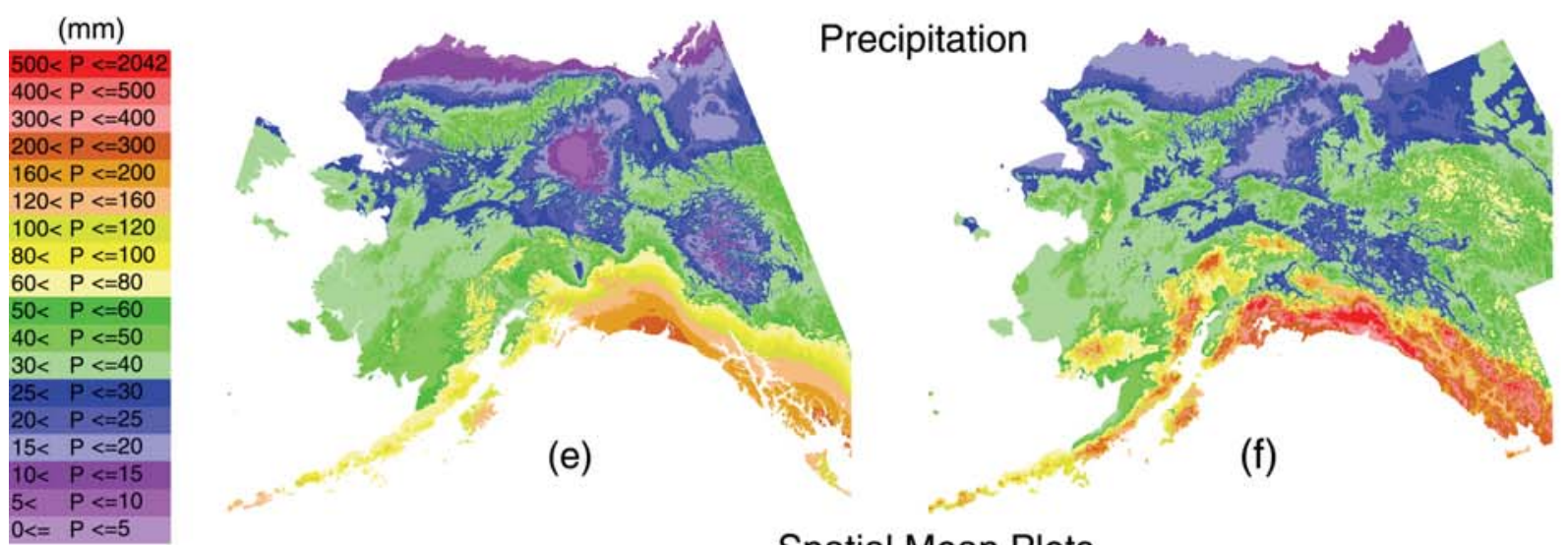

Spatial Mean Plots
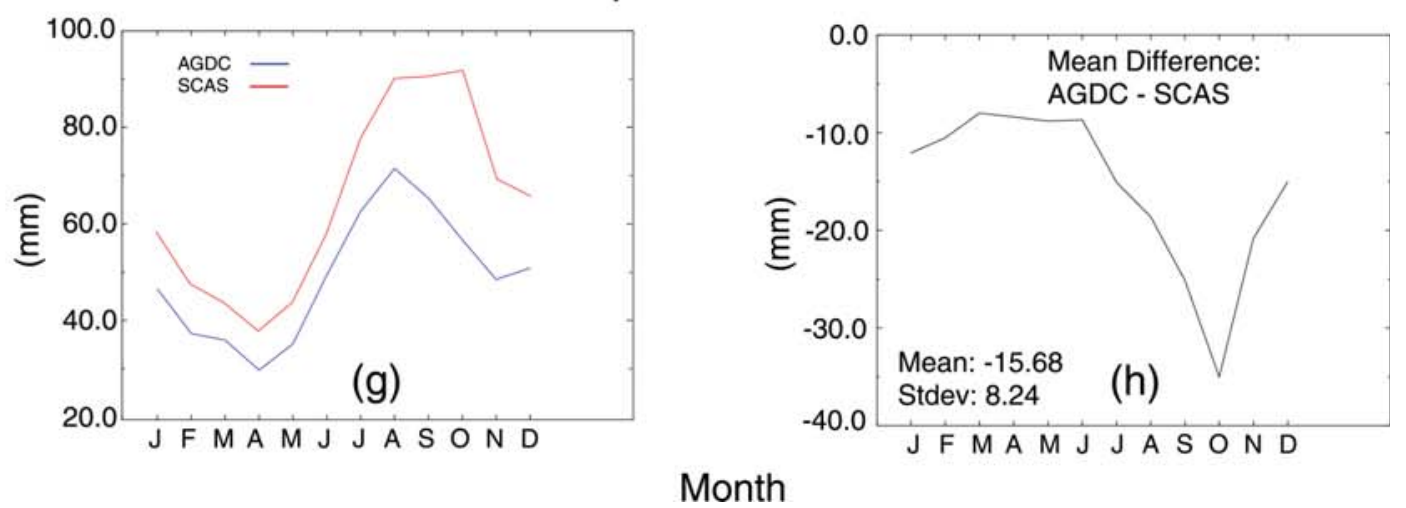

FIG. 8. Annual (12 month) means and spatially averaged monthly means of the variables for the AGDC and SCAS data sets. 
Let $\left\{\mathrm{T}_{\mathrm{i}}(\mathrm{x}, \mathrm{y}), \mathrm{i}=1,12\right\}$ and $\left\{\mathrm{P}_{\mathrm{i}}(\mathrm{x}, \mathrm{y}), \mathrm{i}=1,12\right\}$ be the mean monthly time series of surface temperature and precipitation at a given location $(x, y)$, of either the AGDC or the SCAS data set. Annual maximum and minimum temperature (or precipitation) at a given location were defined as the maximum and minimum values, respectively, in the 12 member sets $\left\{\mathrm{T}_{\mathrm{i}}(\mathrm{x}, \mathrm{y})\right\}$ or $\left\{\mathrm{P}_{\mathrm{i}}(\mathrm{x}, \mathrm{y})\right\}$. Annual maximum temperatures (Fig. 9a, b) occur in the central interior basin of Alaska during the summer in both data sets; however, in the SCAS data set maxima cover a more extensive area. Minima (Fig. 9c, d) in the AGDC data occur in the Brooks Range and the Mackenzie Mountains of northwestern Canada. The SCAS data set also has a minimum in the Mackenzie Mountains, but its other pronounced minimum occurs in the western North Slope, not the Brooks Range. Corresponding maps for precipitation (Fig. 9e, g for AGDC, Fig. 9f, h for SCAS) generally show that maximum mean precipitation occurs in southeast Alaska, the south-central coastal domain, and the outer Aleutian Islands. Minimum precipitation occurs on the North Slope, over parts of the interior basin, and in adjacent areas of Canada.

The month of occurrence of maximum precipitation at each location, for both the AGDC data set (not shown) and the SCAS data set (Fig. 10a), was computed from their respective 12-month data sets. For western Alaska and most of northern Alaska, maximum precipitation occurs in August, consistent with the mean spatial map of precipitation (Fig. 8g). Maximum precipitation for much of southeast Alaska and the Aleutian Islands, however, occurs in October, while for south-central Alaska and most of the Alaska Peninsula, it occurs in September. Eastern and central Alaska and adjacent areas of Canada experience maximum precipitation in July.

Months (January through December) were assigned integer values of 1 through 12 . The difference in the month of occurrence of maximum precipitation at a given location was defined as the number of months between when maximum precipitation occurred in the AGDC precipitation maps and when it occurred in the SCAS precipitation maps. Thus, a positive value indicates that maximum precipitation occurs later in the AGDC maps than in the SCAS maps. Over most of Alaska, the month of occurrence of maximum precipitation is independent of data set (Fig. 10b). Small areas where the largest differences are found generally occur near mountains, where there are gaps in station data. Thus, some of these differences may simply reflect the different ways in which the two interpolating models handle relief, especially in the absence of station data. The most pronounced region of such differences occurs on the leeward side of the Wrangell-St. Elias Mountains. Here, differences appear to result from the "spilling over" of coastal precipitation into inland valleys that occurs with the ANUSPLIN interpolation.

The physical significance of these differences is confirmed by several factors. First, over most of Alaska, the differences are zero. Second, the regions where differences do occur generally correspond to areas of Alaska affected by either mountain blocking or temperature inversions or both. Both ANUSPLIN and PRISM treat these processes very differently in their respective interpolations. Third, areas of differences generally are spatially contiguous over some regional length scale. Isolated point differences generally do not occur, and any such isolated differences should be regarded as noise.

\section{Empirical Orthogonal Function (EOF) Analysis}

EOFs decompose a data set $F(\mathbf{x}, t)$ into separate functions of space $(\mathbf{x})$ and time $(t)$, ranked by variance (Presendorfer, 1988). The notation $\mathbf{x}$, simply implies a generalized spatial coordinate. Here, $F(\mathbf{x}, t)$ is a set of 12 monthly mean scenes (either the AGDC or the SCAS data set) mapped to a common grid. Ocean pixels are not analyzed. The 12-month temporal mean was removed from $F(\mathbf{x}, t)$ because EOFs are designed to extract spatial patterns of temporal (in this case, seasonal) variability. EOFs were computed using a singular value decomposition (Gill et al., 1991).

Because the EOF analysis was performed on mean monthly maps, the temporal amplitudes (TAs) identify the seasons when a given pattern of spatial variability (an EOF) dominated the mean monthly data. Each EOF extracts a percentage of the total variance in the data; the larger that percentage, the more a given EOF captures the total variance of the data set. Interpretation of the zero crossings in an EOF pattern is avoided. Rather, only the relative patterns in each (i.e., higher versus lower values) are emphasized to avoid artifacts that can be associated with the grid on which the original data were sampled (Richman, 1986). Because rotated EOFs cannot be defined with complete objectivity, only unrotated EOFs were used in this study. To help ensure that each EOF is a distinct mode of variability, only the first EOF for each analysis is shown, consistent with the rule of thumb for degenerate EOFs (North et al., 1982).

Here, EOFs are used to extract spatial patterns that define regions in Alaska with similar climatic characteristics. Their associated temporal amplitudes help identify the seasons when the extracted patterns of spatial variability dominated the data. This information helps to identify transition zones between different climatic regimes in Alaska.

Temperature Structure: EOF 1 for the AGDC data set (Fig. 11a) and EOF 1 for the SCAS data set (Fig. 11b) account for $82 \%$ and $77 \%$ of the total variance, respectively. Both compress the variance well. EOF 1 shows that the coastal domains of southeast, south-central and southwest Alaska, the Aleutian Islands, and other Alaskan islands have moderate surface temperature and little variation in surface temperature relative to the large variation found in the upper Yukon valley of Alaska and the Mackenzie River valley. The corresponding TAs (Fig. 11c) are virtually identical for both data sets. They show a strong annual cycle that peaks in July and reaches a minimum in 


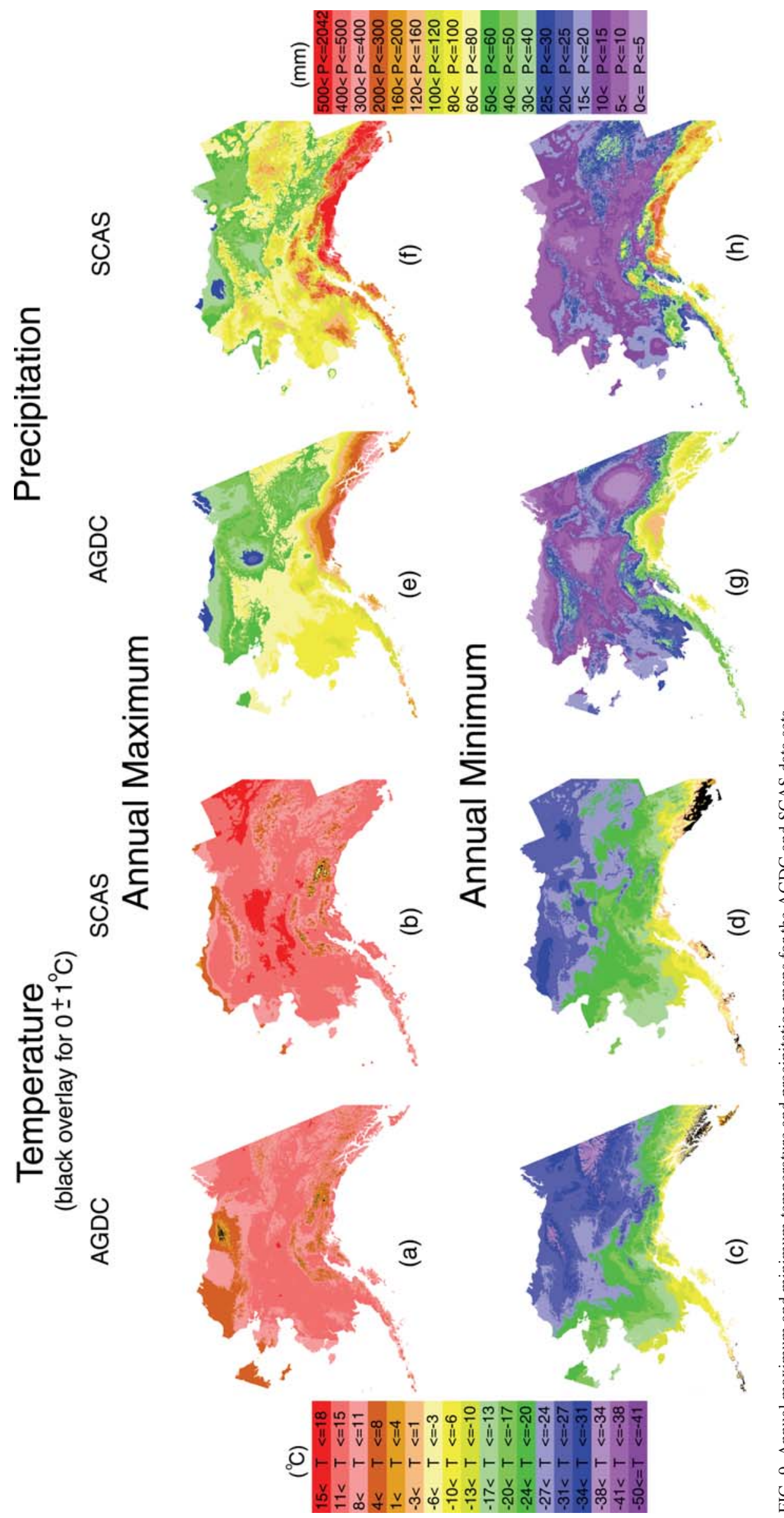

January. TA2 (computed but not shown) also shows a strong annual cycle, with maximum variation occurring in spring (possibly reflecting the spring breakup, which typically occurs in April to early May).

Precipitation Structure: EOF 1 for the AGDC data set (Fig. 11d) and for the SCAS data set (Fig. 11e) each account for $39 \%$ of the variance of their respective data sets. Variance is less effectively compressed because precipitation is more complex than temperature. EOF 1 shows maximum precipitation and extremely high variability in precipitation in the coastal domains of southeast Alaska, southcentral Alaska, the lower parts of southwest Alaska, and the Aleutian Islands. Less variability occurs in the eastern parts of Alaska and adjacent areas of Canada. The upper Yukon valley has minimum precipitation but significant variability in precipitation, consistent with the data in Figure 9.

Again, the TAs for EOF 1 are virtually identical for the two data sets. They have an annual cycle. Major variation in precipitation (compared to the temporal mean) in the southeast occurs in October, and minimum variation occurs in both January and August. TA1 is largely associated with increased precipitation in southeast Alaska and the Aleutian Islands in October (Fig. 10). Both TAs also have a secondary component of annual variability in precipitation associated with maximum summertime precipitation in western and interior Alaska. Here, maximum precipitation occurs in July and August (Fig. 10). It is, however, smaller than the major large-scale onset of increased precipitation which, on average, begins in the southeast in October. TA2 (computed but not shown) also supports this secondary summertime maximum.

Mean seasonal differences in surface temperature and precipitation (Fig. 6) are consistent with the patterns of spatial variability 

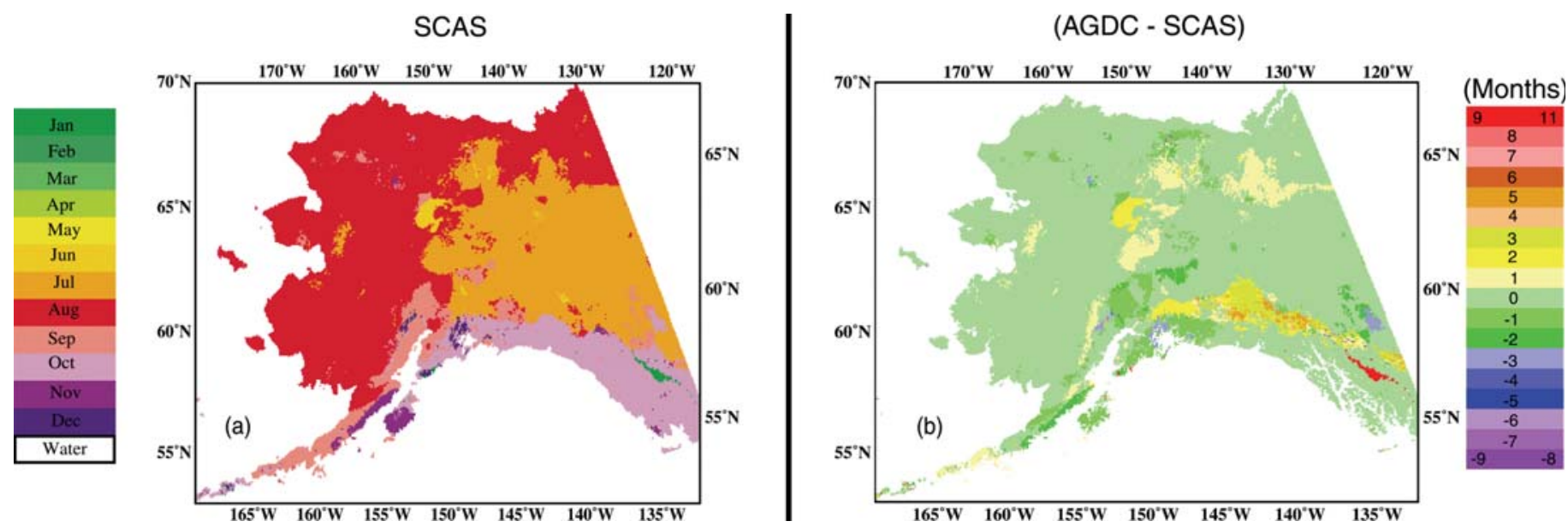

FIG. 10. a) Month of occurrence of maximum precipitation for the SCAS data set. b) Difference (number of months) between AGDC and SCAS data sets in month when maximum precipitation occurs at a given location.

\section{AGDC}

\section{Mean Temperature}

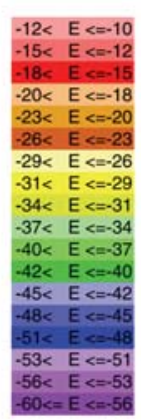

(a) EOF 1 ( $82 \%$ of the variance)

(b) EOF 1 ( $77 \%$ of the variance)

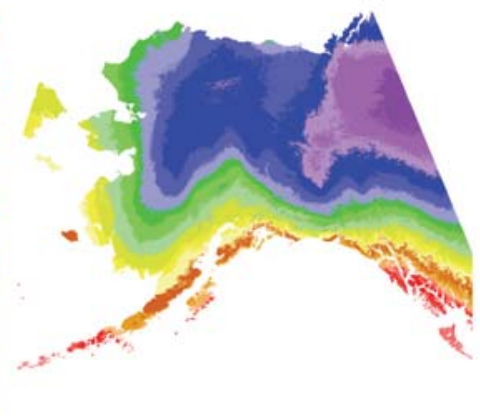

\section{Mean Precipitation}

(d) EOF 1 (39\% of the variance)

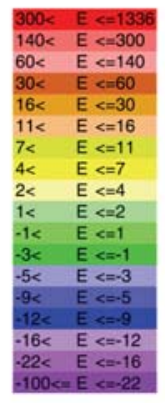

(black overlay for $0 \pm 5$ ) (e) EOF 1 (39\% of the variance)

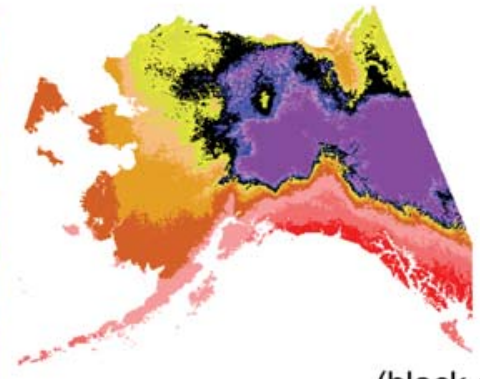

\section{SCAS}

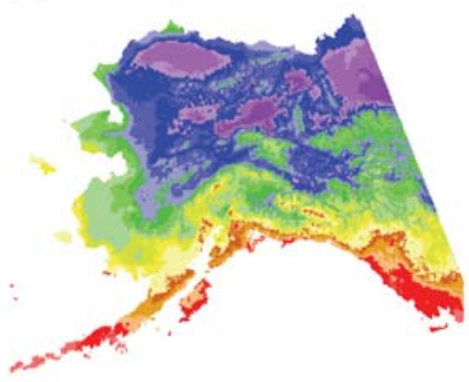

Temporal Amplitudes

AGDC $\square$ SCAS

(c) TA 1

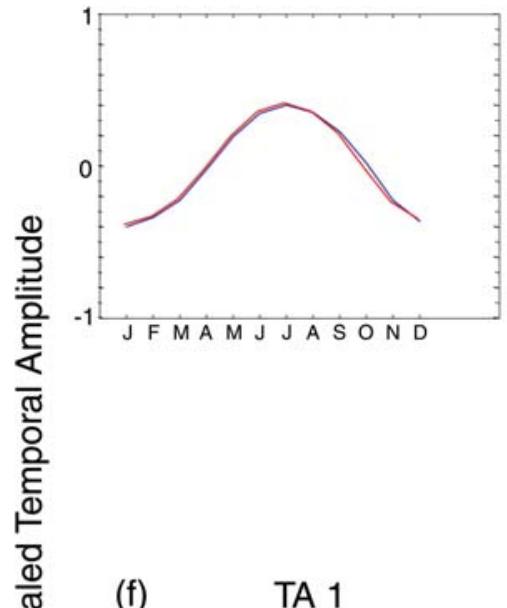

romotom

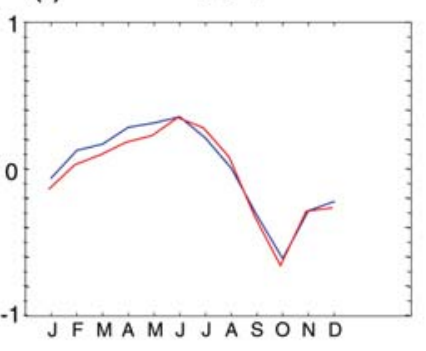

FIG. 11. First EOFs and temporal amplitudes (TA) for surface temperature and precipitation, as marked. Black indicates near-zero values. E denotes EOF color scale values.

observed in the EOFs. They also show that the coastal regions of southeast Alaska, western Alaska from Bristol Bay to Seward Peninsula, the North Slope, and the Aleutian Islands are regions of consistent seasonal variation in temperature and precipitation. Eastern Alaska and adjacent areas of Canada also show consistent seasonal variability in precipitation. Here, the variability is less and different from (of opposite sign to) that of southeast Alaska. The mean seasonal differences shown in Figure 6 also indicate that the variability in surface temperature and precipitation 
in the Alaska Peninsula is distinct from that in the Aleutian Islands. The Alaska Peninsula pattern appears more like that of the coastal domain of southwestern Alaska, while the Aleutian Islands pattern appears more like that of southeast Alaska (with less precipitation than in the southeast, but more than in western Alaska).

\section{Two Alaskan Ecosystems}

Simpson et al. (2002) presented the first Alaskan vegetation ecosystems map based on a phenological classification (see Fleming, 1997, 2000), which contains the major representative vegetation and land cover classes found in Alaska. The phenological classes used to produce the map were determined using an unsupervised clustering algorithm and a maximum-likelihood classifier applied to a Normalized Difference Vegetation Index (NDVI) derived from Advanced Very High Resolution Radiometer (AVHRR) data.

The Alaskan vegetation classes and the spatial climate data from the AGDC and SCAS data sets were used to calculate climate statistics (Fig. 12) for two of the vegetation classes defined by Simpson et al. (2002). The climograph produced using the SCAS data for the southeast Alaskan coastal rain forest shows somewhat warmer and much wetter climate than that produced with the AGDC data. Southeast Alaska is one region where differences in mean monthly precipitation between the AGDC and SCAS data sets tend to be largest. These results also show that relatively small differences occur for the interior boreal forest ecosystem. This is consistent with the facts that for interior Alaska, the AGDC and SCAS data sets have very similar mean monthly surface temperatures, and that the interior boreal forest is very dry compared to the southeast Alaskan coastal rain forest (see Figs. 4, 5, 8).

\section{DISCUSSION}

Although differences, especially for extremes in precipitation, exist between the AGDC and SCAS maps, the EOF analyses show that these differences do not affect the common spatial and temporal patterns of variability extracted from the data or conclusions about large-scale seasonal patterns in Alaskan temperature and precipitation. Here we 1) report the major observed differences between the two sets of maps; 2) compare both sets of maps to independent data and analyses where possible (e.g., for the North Slope); and 3) show where both sets of maps may err because data are insufficient, inaccurate, or both.

\section{Comparison between the AGDC and SCAS Maps}

Temperature: The large-scale mean temperature maps of the AGDC and SCAS data sets generally agree (Figs. 4, $8,9)$. Warmest temperatures are usually found in the
SCAS data set, coldest temperatures occur in the AGDC data set, and the annual variance of the SCAS data set is about $10 \%$ larger than that of the AGDC data set. Departures from this pattern, however, do occur.

A possible general source of temperature differences between the two data sets is the treatment of temperature inversions by the PRISM model, not accounted for in the ANUSPLIN interpolation. The difference histograms (Fig. 4) show that the temperature differences are greatest in the winter, with the SCAS data set showing warmer temperatures than the AGDC data set. In the Alaska interior (e.g., Yukon Flats), a persistent temperature inversion dominates the thermal regime, with very cold air pooling in low-lying areas. The result is very cold temperatures in valleys and warmer temperatures in surrounding mountains. Stations used by the ANUSPLIN interpolation were nearly all located in valley bottoms, and no upper-air temperature data were used; this created a cold bias in the temperature estimates of the interior uplands. On the other hand, PRISM modeled the atmosphere in two layers: the near-ground boundary layer, represented by valley observations, and the free atmospheric layer, represented by mountain stations and upper-air reanalysis temperatures, both of which reflect a warmer layer above the valley floors.

One of the most significant regional differences in temperature occurs in the Brooks Range and North Slope (Fig. 13). The area can be broken into four zones, partially delineated by distance from the ocean: the Arctic coastal zone, the Arctic inland (coastal plain), the Arctic foothills, and the Brooks Range (Kozo, 1982; Zhang et al., 1996). An interior foothill region occurs on the southern flank of the Brooks Range, analogous to the Arctic foothills on its northern flank. The Arctic coastal zone is a narrow band along the coast. It is directly influenced by the Arctic Ocean, but this influence is damped in winter when the ocean is ice-covered. Observations of sea breeze characteristics are consistent with a $20 \mathrm{~km}$ width scale for this zone (Kozo, 1982). The Arctic inlands extend about $100 \mathrm{~km}$ inward from the interior edge of the Arctic coastal zone. The Brooks Range is broad, with distinct foothills, and is indented with numerous valleys and canyons.

For the winter months, the AGDC data set associates very cold temperatures with the Brooks Range, showing slightly warmer temperatures in the foothills, warmer temperatures in the Arctic inland zone, and generally warmest temperatures along the Arctic coast (Fig. 13a). The SCAS data set, however, shows less temperature variation, with a relatively warm Brooks Range, a colder Arctic inland zone, and a relatively warm coastal zone near Barrow (Fig. 13b). One reason for this may be that the input data to the PRISM model included stations in the Brooks Range (e.g., stations at Anaktuvuk, Wild Lake, Coldfoot Camp, and Galbraith [Fig. 1b]), whereas the input data to the ANUSPLIN model did not (Fig. 3). Moreover, the PRISM model recognizes that the Brooks Range largely rises above a persistent winter temperature 


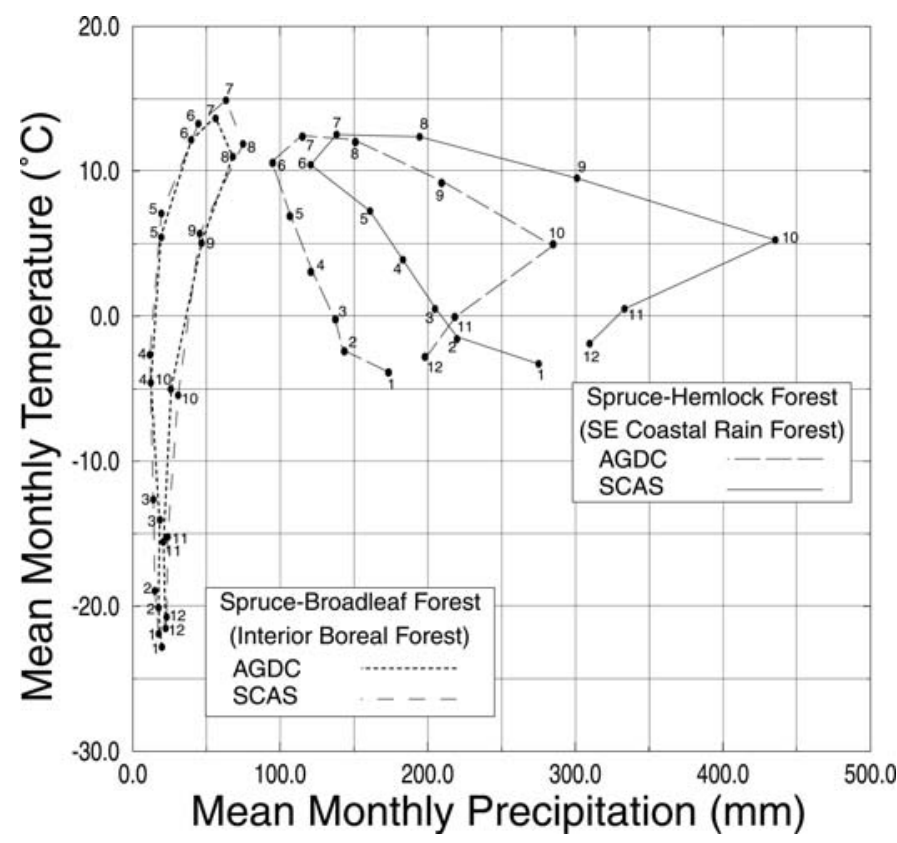

FIG. 12. Climographs for two Alaskan ecosystems.

inversion, and hence is not as cold as the Arctic inland zone. PRISM also has a coastal proximity algorithm that limits inland extent of marine boundary layer effects. Both data sets show well-defined and distinct temperatures for both these regions in the summer. However, the SCAS data set (Fig. 13d) shows a much more consistent regional pattern, with cool temperatures along the coast and warmer temperatures in the Arctic inland zone, returning to cooler temperatures at the higher elevations of the foothills and the Brooks Range, consistent with the independent field observations of Zhang et al. (1996). The more fractured summertime regional pattern of the AGDC data set (Fig. 13c) is strongly influenced by data from Umiat, which because of its location (Fig. 1b) may not be representative of the entire region. Temperature-height and precipitation-height relationships in this region are poorly known, and the complex terrain makes them hard to model.

This region is also generally underrepresented in the station data. Only one set of Snotel stations traverses the Brooks Range, along the Alaskan pipeline route (Fig. 1b). Here, the highest elevation station occurs at Atigun Pass (elev. $1463 \mathrm{~m}$ ). The highest elevations of the Brooks Range, however, generally occur northeast of Atigun Pass (Fig. 1b), with elevations between 1219 and $2743 \mathrm{~m}$ (mean elevation about $2134 \mathrm{~m}$ ). Both the AGDC and SCAS data sets show some of their coldest wintertime temperatures in this part of the Brooks Range, consistent with the location of glaciers (Wendler et al., 1974). Although the relative patterns of temperature here agree, the absolute accuracy of the temperature in this domain is uncertain.

The USGS's Digital Elevation Model (DEM), used by both the ANUSPLIN and PRISM interpolators, varies in accuracy and vertical resolution across Alaska. ANUSPLIN uses the basic DEM $(15 \times 15$ arcsecond resolution $)$ but resampled to $30 \times 60$ arcseconds prior to use. For PRISM, the GTOPO30 DEM was low-pass filtered to 2.5-minute resolution. Inadequacies in the DEM representation of the region and differences in its input resolution to the two models may partially account for some of the cited
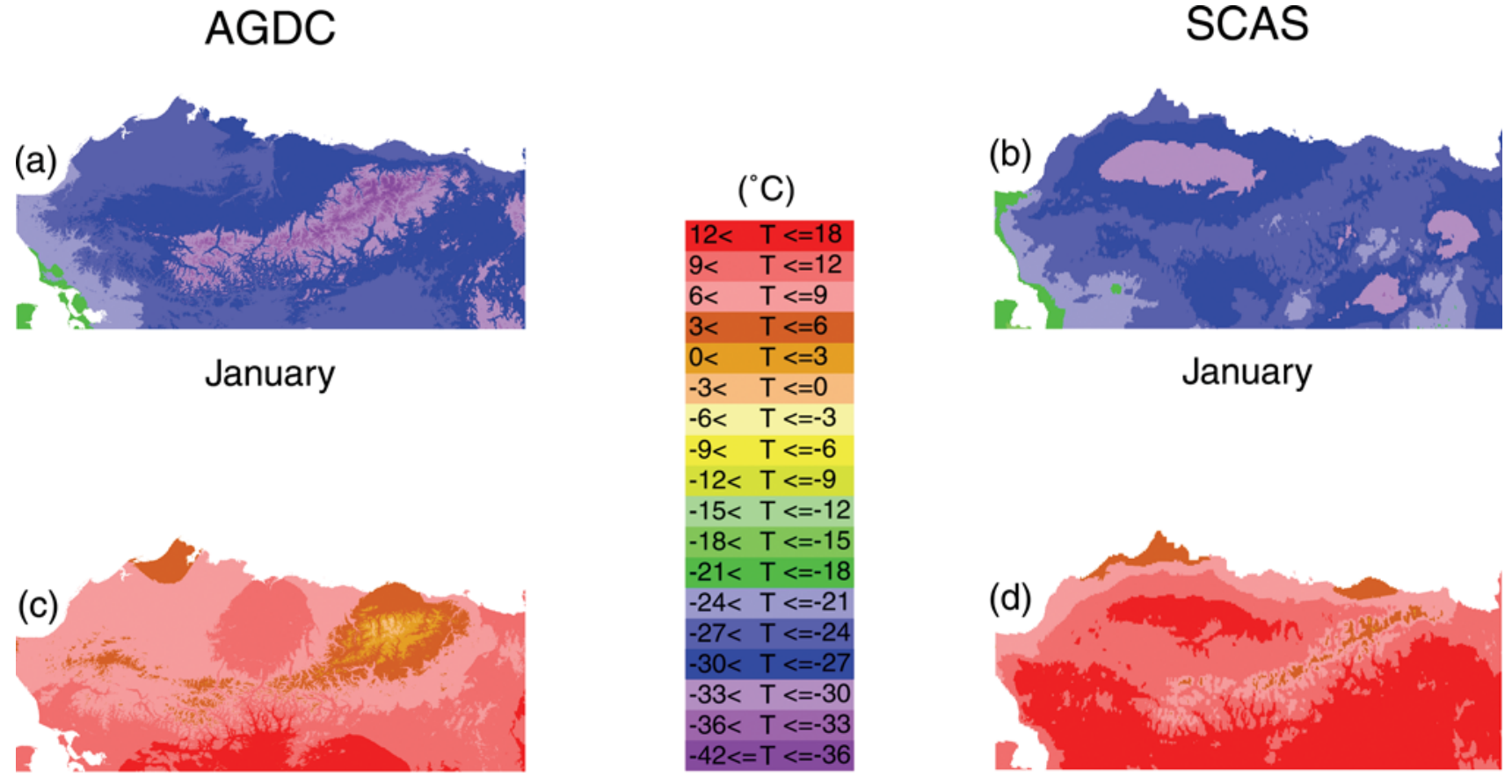

July

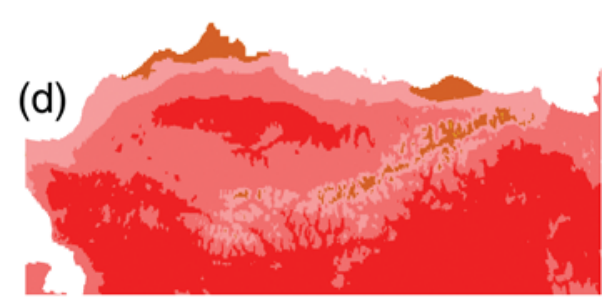

July

FIG. 13. Mean monthly surface temperature (T) from the Arctic coast to the south flanks of the Brooks Range region for January and July (AGDC and SCAS data sets). 
discrepancies between the AGDC and SCAS data sets. Some temperature differences may be due to differences in the time period of their respective input data (see below).

Precipitation: The large-scale seasonal patterns of precipitation represented in the two data sets generally agree, but the maximums differ significantly, especially in the coastal mountain areas. Both models produce relatively low precipitation in the interior, especially in the Yukon Flats. The SCAS data set shows this area as wetter because unshielded gauge data, which are known to suffer from significant undercatch, were not used. This is also the case on the north coast, where GHCN unshielded gauge data were replaced with shielded Snotel gauge data in the PRISM analysis.

Mean monthly precipitation (January, July) for the southern Alaskan mainland, as shown by the AGDC data set (Fig. 14a, d), the SCAS data set (Fig. 14b, e), and their differences (Fig. 14c, f), has several interesting regional features. First, the SCAS maps show higher precipitation on the northwest side of Prince William Sound than the AGDC maps, consistent with the distribution of snowfall and the 54 glaciers in this region. This result is due to PRISM's ability to extrapolate precipitation-elevation relationships on the windward slopes of the coastal mountains using sparse data. This feature also allows PRISM to simulate the precipitation maximum on the southern (windward) slopes of the Ahklun Mountains, north of Bristol Bay, not readily seen in the AGDC maps. Second, the SCAS data set shows the rain shadow effect of the mountains (Wrangells, Kenai, Chugach, and Alaska Range) on the distribution of precipitation more accurately than does the AGDC data set. The Kenai and Chugach mountains partially shelter Anchorage from precipitation. For example, Whittier, about $80 \mathrm{~km}$ southeast of Anchorage on the windward side of the mountains, gets over $5000 \mathrm{~mm}$ of precipitation per year, while Anchorage gets only about $400 \mathrm{~mm}$.

The Kobuk River basin of northwest Alaska (Fig. 2) is surrounded by mountains on three sides (the Brooks Range to the north, the Nulato Hills to the south, and Purcell Mountains to the east) and is open to the ocean on the west. These marine and continental influences make the region extremely difficult to model. Here, the SCAS data set has higher precipitation estimates than the AGDC data set (Fig. 5).

The AGDC and SCAS data sets both associate a distinct precipitation region with the Brooks Range throughout the year, but there are some differences (Fig. 5). The AGDC data set has a more spatially uniform dry North Slope in the winter compared to the SCAS data set, which shows a drier western and eastern North Slope separated by a wetter central North Slope. This may be due to the selection of shielded gauge data over unshielded data, adjustment of the Umiat precipitation data to account for undercatch, and additional Snotel precipitation data in the Brooks Range used in the PRISM analysis. Both the AGDC and SCAS data sets show an increase in precipitation southward from the Arctic Ocean towards the Brooks Range, consistent with observations of Zhang et al. (1996).

Interpretations: Several interpretations of the intercomparisons are possible. Large differences between the two climatologies may indicate large uncertainties in the climatologies, while small differences can imply either that the uncertainties are small, or that both analyses have large but similar errors. Another interpretation is that differences occur because one analysis is superior to the other. Given the major differences between the suites of methods, including but not limited to the different model architectures and input data sets used by the AGDC and SCAS groups, it is unlikely that the AGDC and SCAS maps would have large and similar types of errors in most locations modeled. Therefore, we assert that it is reasonable to presume that most small differences between the two sets of maps can be correctly interpreted as relatively small uncertainties in the two climatologies.

\section{Accuracy of Precipitation Estimates in Alaska}

Interpolation of irregular site data is difficult. There is no satisfactory method for accurately calculating largescale averages of precipitation from sporadic gauge data, and the ideal measurement unit or process to extend point observations to the large scale is unclear (Hulme, 1995). Generally, precipitation increases with elevation, but this is not easy to quantify in an interpolation scheme, and the $\mathrm{P}$ vs. Z relation can be unexpectedly nonlinear and spatially and temporally variable. The representativeness of a given $\mathrm{P}$ vs. $\mathrm{Z}$ relation is often questionable because gauges in mountainous regions are usually in valleys. Also, conversion of snow to snow water equivalents is difficult. Thus, it is not surprising that the AGDC and SCAS estimates of Alaskan precipitation vary more than those of temperature, especially in mountain regions.

Local seasonal and total annual percent differences in precipitation were computed (AGDC - SCAS) / ((AGDC + SCAS) $/ 2$ ); they provide a normalized measure unaffected by the strong relationship between mean value and variation in precipitation. These data and their corresponding histograms (Fig. 15) show that for most of Alaska, the local percent seasonal difference between the AGDC and SCAS estimates of precipitation is small (e.g., for July $85 \%$ of all the differences are $\leq 50 \%$ ). As expected, certain areas (e.g., the mountains of southeast Alaska) have relatively large percent differences. These modeled differences, however, are consistent with reported differences between various estimates of precipitation for southeast Alaska, e.g., the $46 \%$ difference between the maximum estimates of Branton and Watson (1969) and Kilday (1974).

These maps also show the difference between the two models in mountain blocking. Pronounced seasonal storm track changes occur in Alaska (also see Simpson et al., 2002). Maximum precipitation occurs in interior and western Alaska during July and August, respectively (Fig. 10), 


\section{Precipitation}

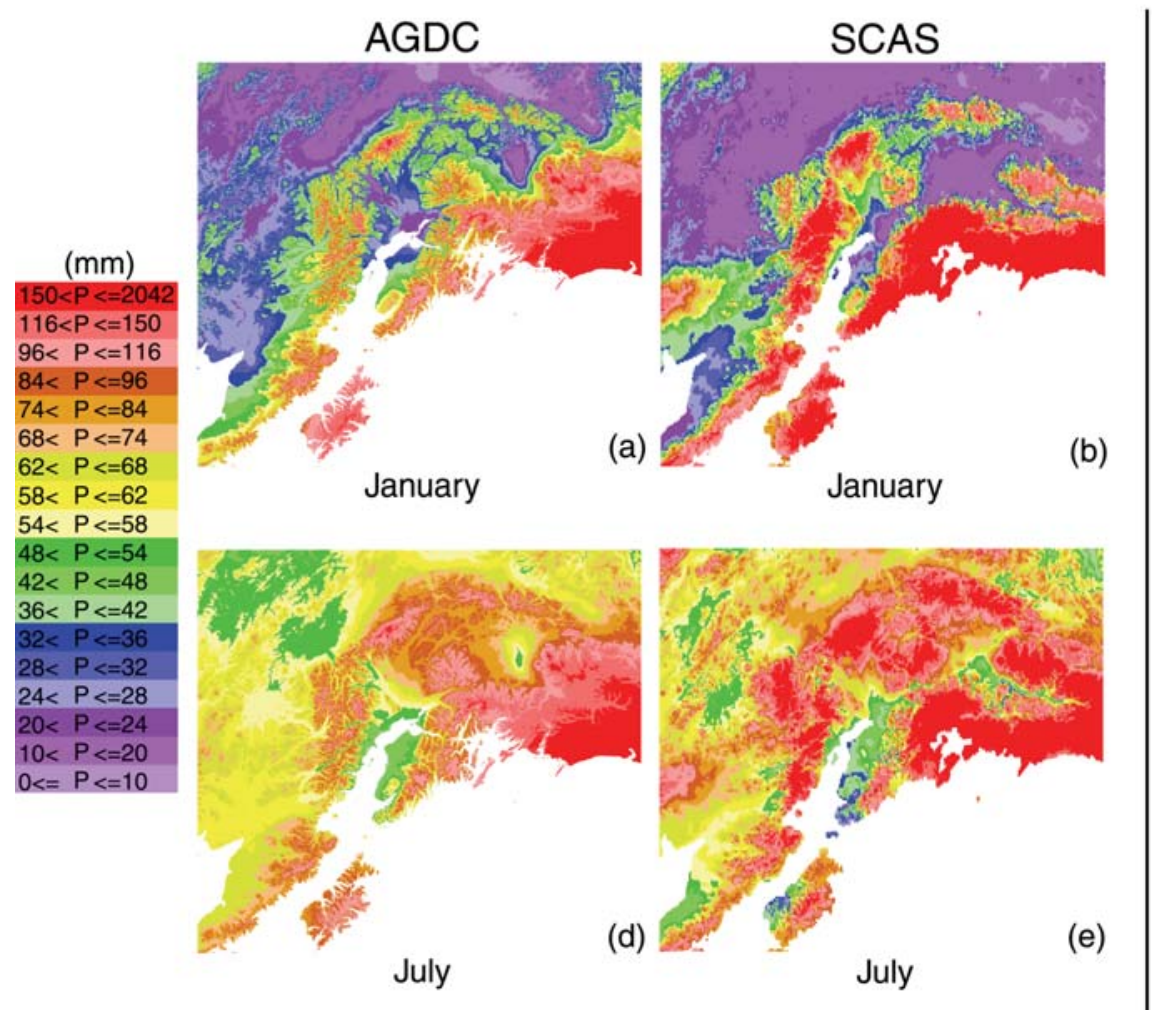

Precipitation Difference

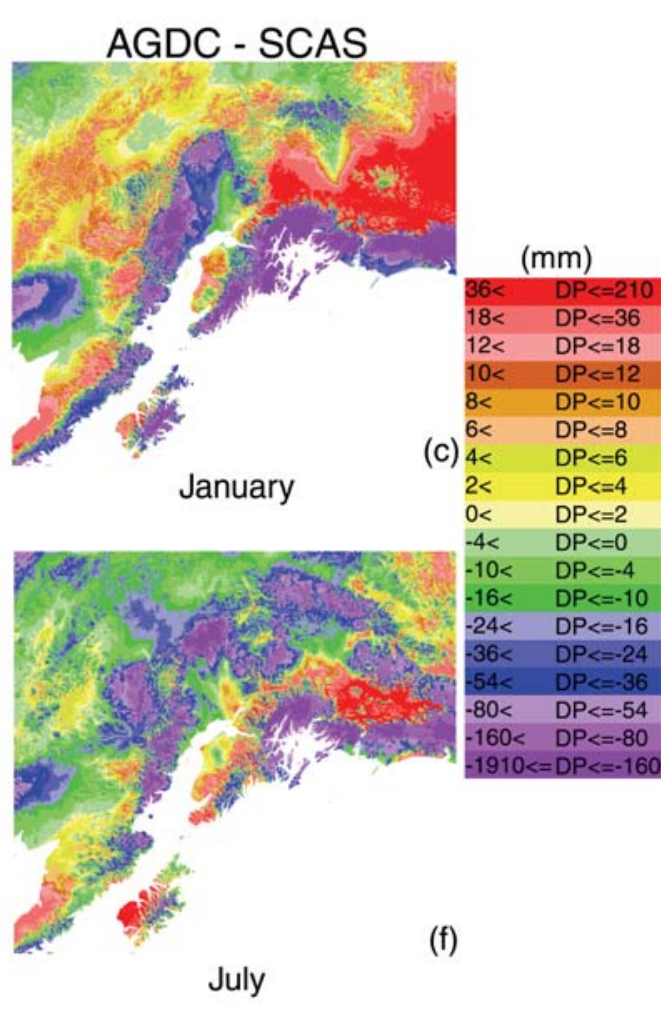

FIG. 14. Mean monthly precipitation (P) for the southern Alaska mainland as indicated. Panels $\mathrm{c}$ and $\mathrm{f}$ show differences with the color scale denoted by DP.

in response to Bering Sea storms crossing into the central Alaska mainland. Significant precipitation from the Gulf of Alaska does not occur until September and continues into the winter (Fig. 10). While the mountains would act as a barrier to southerly flow during the winter, the generally east-west orientation of the Brooks Range and the Alaskan Range means they tend to funnel storms inland from the Bering Sea during summer. The data (Fig. 15) suggest that the PRISM model tends to handle the orographic effects of the Alaska Range, the Chugach Mountains, and the Wrangell-St. Elias Mountains much better than the ANUSPLIN model.

The Aleutian Range, which runs from the Alaskan Peninsula the full length of the Aleutian Islands, is generally considered an extension of the Alaska Range. Complex terrain characterizes this region of Alaska, from near sea level to peaks exceeding $3658 \mathrm{~m}$ (Mt. Shisaldin). PRISM uses input data from five stations on the Alaskan Peninsula (Chignik, Sand Point, Nelson Lagoon, Cold Bay, Point Heiden, Fig. 1c). None of these locations, however, is ideal for accurately measuring precipitation that is representative of the Alaskan Peninsula as a whole. Sand Point and Chignik, for example, are on the beach, with the towns very close to the mountains. Frosty Peak $(2438 \mathrm{~m})$ is close to Cold Bay and blocks precipitation from the northwest. ANUSPLIN uses input data from only two stations in this region, Cold Bay and Dutch Harbor, and these stations suffer from the same limitations cited above. Moreover, the Aleutian Islands extend from $160^{\circ} \mathrm{W}$ to $170^{\circ} \mathrm{E}$ and have only three stations to cover over $1610 \mathrm{~km}$. And the Aleutians regularly experience high wind events.

A sparse network of poorly located stations, generally instrumented with unshielded gauges, makes precipitation observations in this region suspect. Given the well-documented seasonal change in storm track direction (with corresponding variation in air mass characteristics), on a mean monthly time scale we might expect to see variation in wind shadow effects in modeled precipitation. Neither the AGDC nor the SCAS data set shows this pattern (Fig. 14). The station data available to the ANUSPLIN and PRISM models simply may be unrepresentative of the true variability in precipitation. A denser and improved station network is required to address this potential issue.

\section{In Situ Validation}

Both the AGDC and SCAS groups used the maximum number of in situ station records available to them to improve the accuracy and representativeness of their mean monthly climate maps. This constraint, plus the general lack of high-quality climate observations for Alaska, makes independent in situ validation difficult. Nonetheless, we have identified a few independent candidates for in situ validation of the AGDC and SCAS Alaskan mean monthly maps. 
January
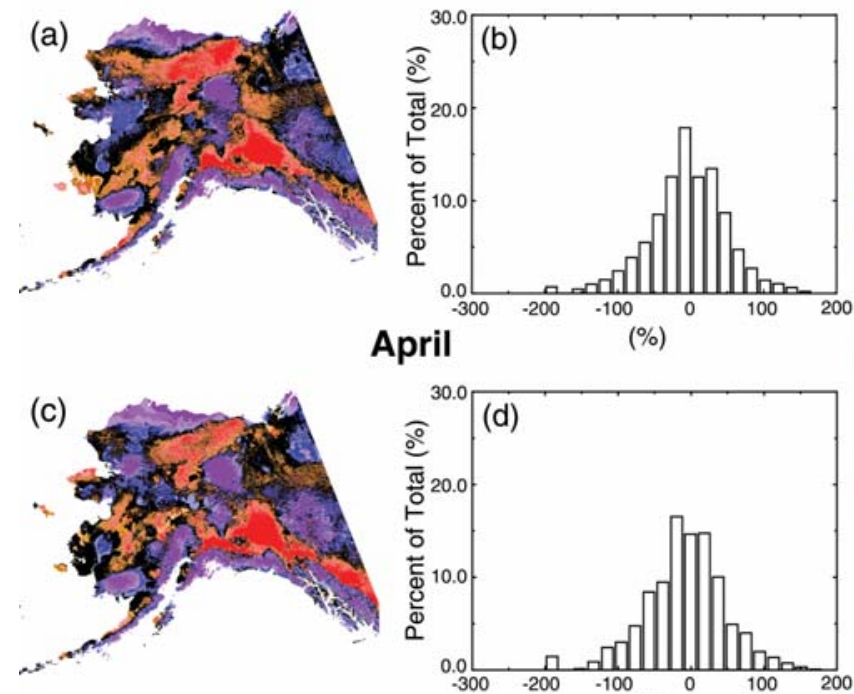

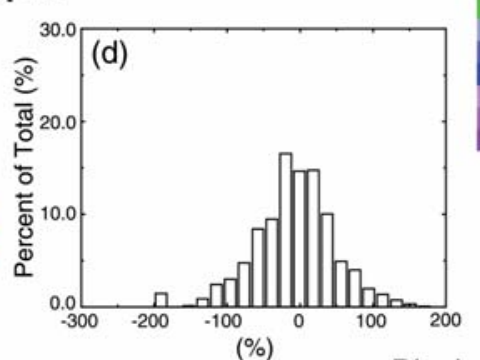

(\%)

Black overlay for $0 \pm 20 \%$

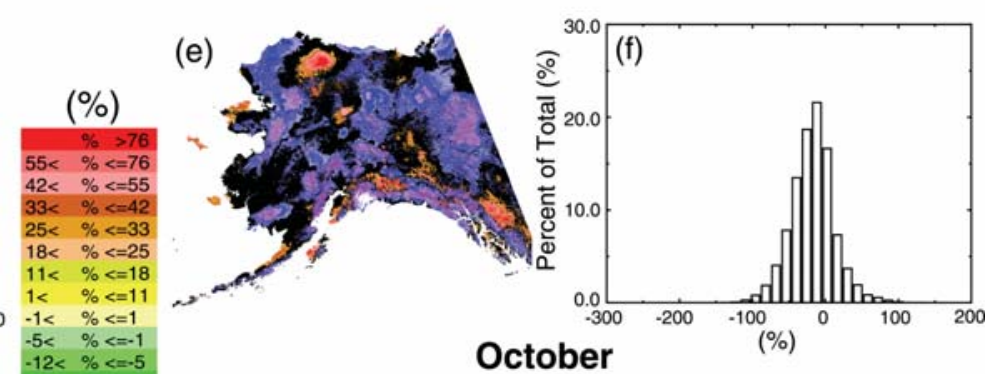

\section{$(\%)$}

$-12<\%<<=5$ $-19<\%<<<12$
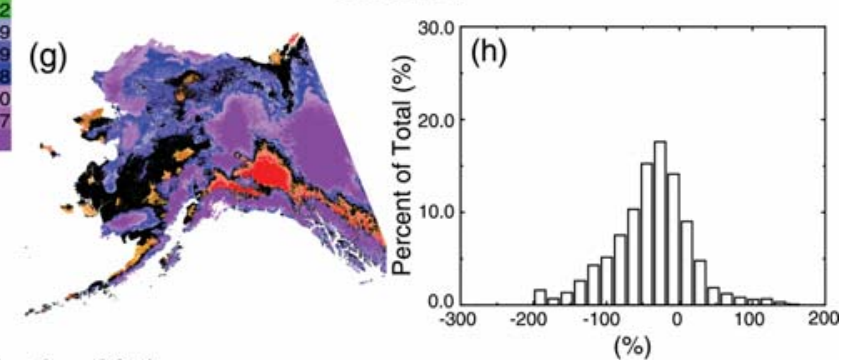

\section{Annual}

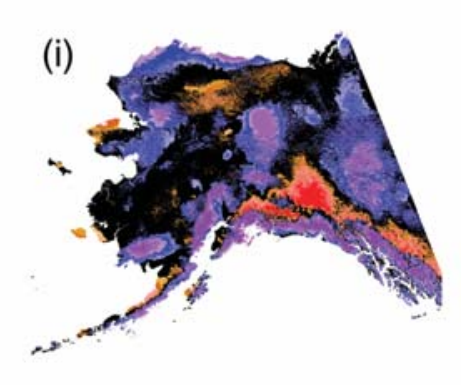

(\%)
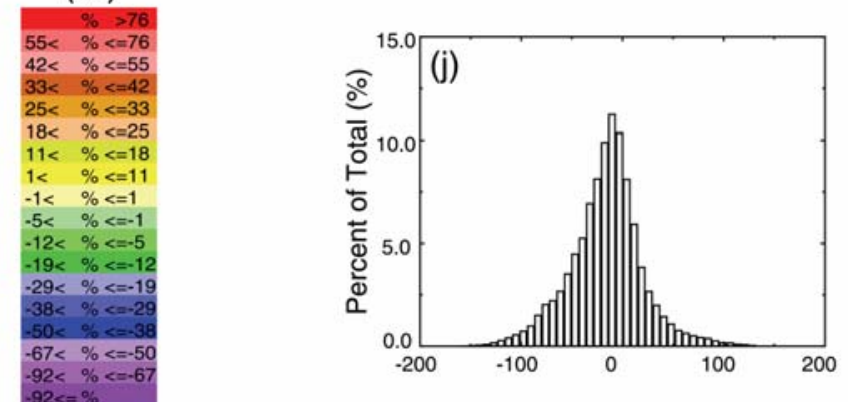

FIG. 15. Seasonal and annual precipitation differences between the AGDC and SCAS datasets (\%), as indicated. See text for details.

Temporal Trends: A comparison of the monthly mean temperature station data for Anchorage and Fairbanks used by the AGDC and SCAS groups shows that the AGDC temperatures were colder than those used by SCAS by about $0.5^{\circ}$ to $1^{\circ} \mathrm{C}$. In the GHCN data used by AGDC, the averaging period was 1916-93 for Anchorage and 192993 for Fairbanks, while the SCAS analysis used an averaging period of 1961-90 for both stations. The difference between the two data sets (SCAS is warmer than AGDC) appears to be due to differences in the averaging periods because both sets of data were drawn from essentially the same measurements. The data for these two stations suggest a warming trend in Alaska, a trend which is seen in the statewide average monthly temperature differences between the AGDC and SCAS data sets (Fig. 8c, d).

Independent analyses by the Alaska Climate Research Center (http://climate.gi.alaska.edu/ClimTrends/30year/ $30 \mathrm{yr} . \mathrm{html}$ ) support the differences in the AGDC and SCAS data sets cited above. Running mean (30 year) annual temperatures for major Alaskan cities show that warming trends began around 1950 and continue. Urban warming may also contribute to some of the trends shown. Moreover, trend analyses for other Alaskan locations unlikely to be affected by urban warming are also consistent with the warmer SCAS surface temperatures compared to those of the AGDC data set (Figs. 4, 6, 8). While these warming trends appear to be statewide, Kodiak does provide an exception. This may reflect the exclusively marine climate of Kodiak Island compared to the more continental climate of most of Alaska. Lastly, the near-statewide warming trends are further supported by a long-term (1981-2001) upward trend in vegetation greenness for Alaska tundra found by an independent analysis of satellite data (Jia et al., 2003).

Spatial Structure: The AGDC temperature map for January (Fig. 13a) indicates that temperature decreases monotonically along a transect from the Arctic coast to the Brooks Range. The corresponding SCAS transect, unlike that of the AGDC data set, has coldest temperatures in the 


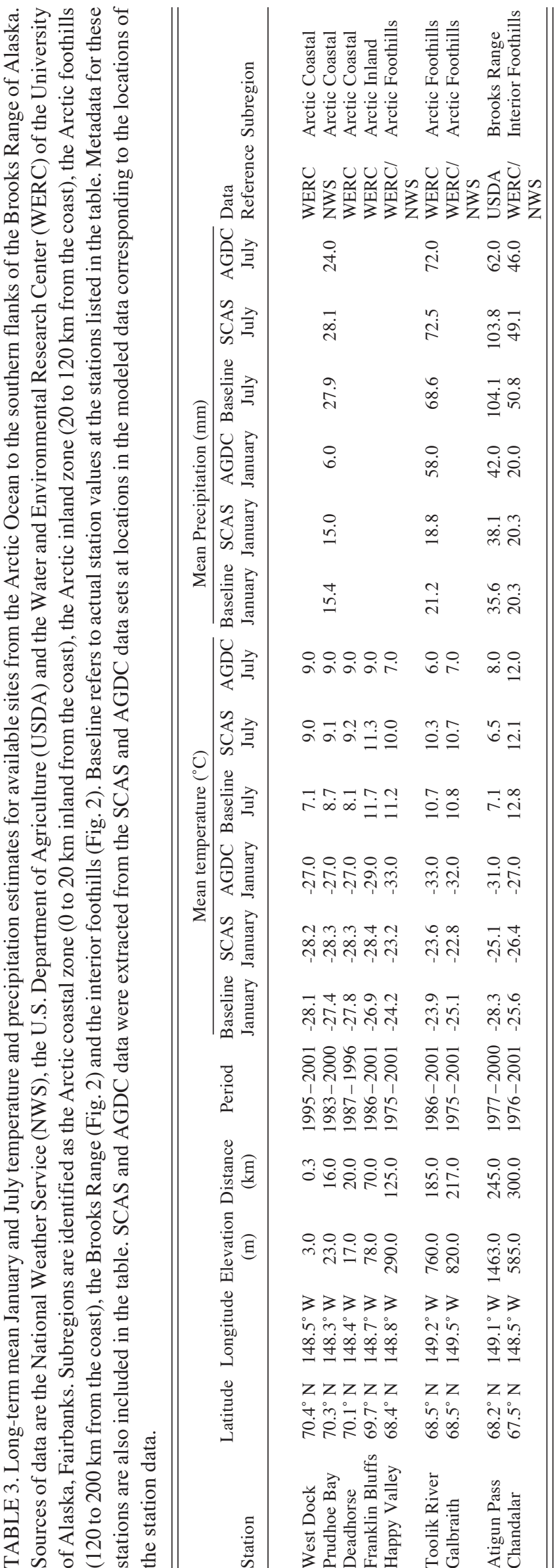

Arctic inland zone and more moderate temperatures along the Arctic coast and in the Arctic foothills and the Brooks Range (Fig. 13b). For July, cooler temperatures in the SCAS data set (Fig. 13d) occur in the Arctic coastal zone, warmest temperatures occur in the Arctic inland zone, and colder temperatures again appear in the Arctic foothills. Coldest temperatures occur in the Brooks Range, and relatively warmer temperatures again occur in the interior foothills of the Brooks Range near Chandalar. The corresponding AGDC map (Fig. 13c) is dominated by a "bull'seye" associated with data from Umiat. Except for this warmer bull's-eye pattern, the AGDC temperature distribution is relatively uniform from the Arctic coast to the Brooks Range, where coldest temperatures occur. Temperatures again become warmer in the interior foothills. Both the AGDC and the SCAS precipitation maps (Fig. 5a, $\mathrm{b}, \mathrm{i}, \mathrm{j}$ ) show increasing precipitation along a transect from the Arctic coast into the foothills, with maximum precipitation occurring in the Brooks Range. Precipitation decreases as the transect descends the southern flanks of the Brooks Range into the interior foothills. This pattern occurs in January and July in both data sets, but the amount of precipitation for the region is much greater in July than in January.

Time series of temperature and precipitation were examined for nine stations that transect the region of interest, from West Dock directly on the Arctic Ocean beach to Chandalar in the interior foothills on the southern side of the Brooks Range (Table 3). Most of these records cover 15 years or longer, and the vast majority of this data was not used by either the AGDC or the SCAS groups to produce their respective mean monthly Alaskan maps. Mean values of temperature and precipitation for January and July (Table 3) were computed using all valid available station data at a given location. These mean station values of surface temperature and precipitation (black triangles in Fig. 16) are plotted as a function of the station's linear distance from the coast. These data provide a baseline against which to compare the AGDC and SCAS data. Corresponding data were extracted from the AGDC and SCAS data sets; they appear as red squares and blue circles, respectively, in Figure 16. The smoothed curve drawn through each set of values provides a shape function for that data set along the transect. The SCAS data are much more consistent with the baseline (independent in situ data) than the AGDC data are. Because the averaging periods of all three data sets are different, some variation in magnitudes among the three data sets is expected. Overall, the SCAS temperature shape functions for this region are more consistent with the station data (Fig. 16) than the corresponding AGDC shape functions. Both data sets have January and July shape functions for precipitation consistent with the station data for precipitation (Fig. 16), but the AGDC data are too wet in January and too dry in July.

Four transects (Fig. 17a) were selected to represent the region in greater detail. Along each transect, mean surface temperature and precipitation values for January and July 

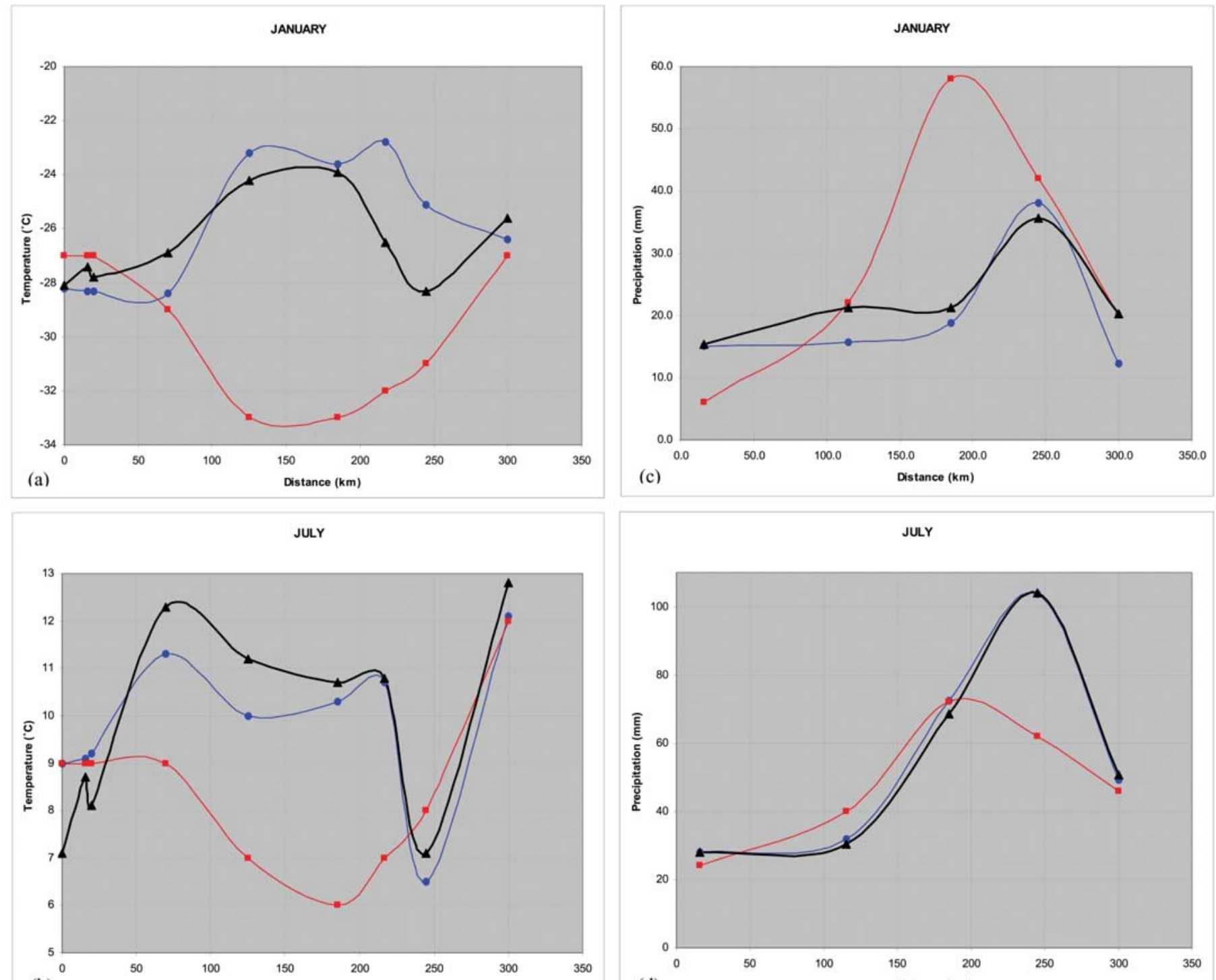

(b)
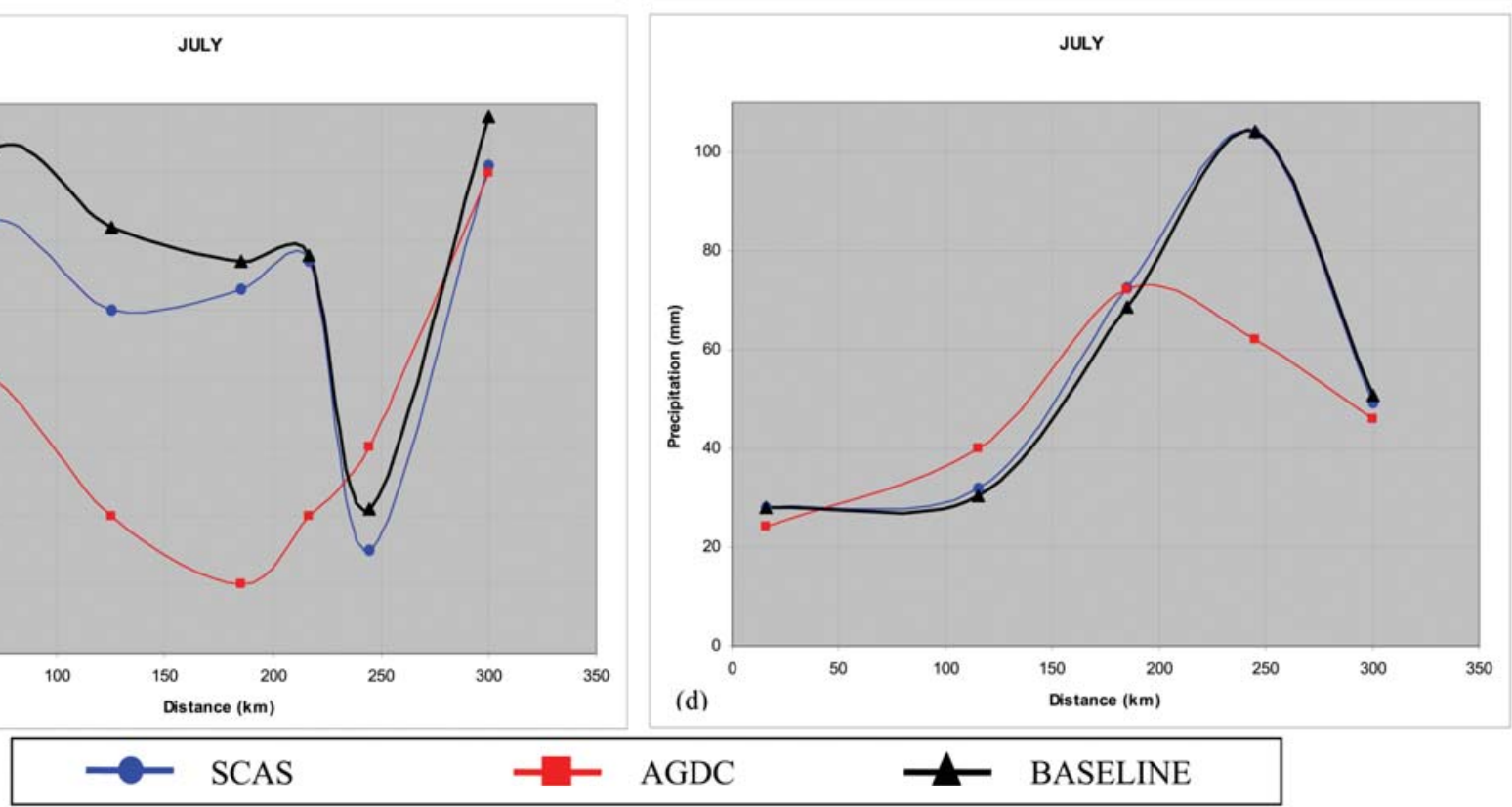

(d)

\section{AGDC}

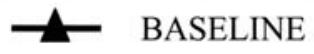

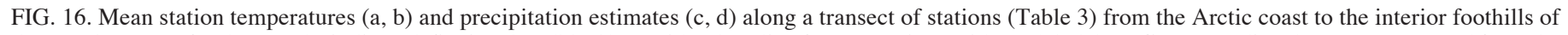

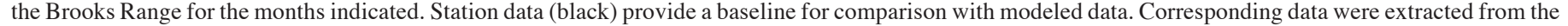
AGDC data set (red) and the SCAS data set (blue).

were extracted from both the AGDC and the SCAS data sets. A shape function for each of these records was computed by low-pass filtering the record with a running mean symmetric spatial filter of length 25 . At the ends of the series, one-sided (often called skewed) means were used. Panels b, d, f, and h in Figure 17 show the smoothed mean January and July surface temperature and precipitation shape functions obtained using the AGDC data. Corresponding shape functions obtained using the SCAS data appear in Figure 17, panels c, e, g, and i. The distinct thermal regions cited earlier (Arctic coastal zone, Arctic inland zone, Arctic foothills, Brooks Range, interior foothills) are easily seen in the SCAS data. The AGDC data set fails to produce a colder Arctic inland zone in winter (here the Brooks Range is the coldest) because the ANUSPLIN model used to produce the AGDC data set does not model the wintertime atmospheric inversions common to Alaska's mountainous valleys. The ADGC data set also does not show the very warm summertime of the Arctic inland region, which contrasts markedly with the cooler coastal zone, the Arctic foothills, and the Brooks Range, as observed by Zhang et al. (1996).

\section{Towards Improving the Observational Network for Alaska}

We offer the following suggestions, based on the analyses presented herein and those of Simpson et al. (2002), for improving the observational surface network in Alaska: 


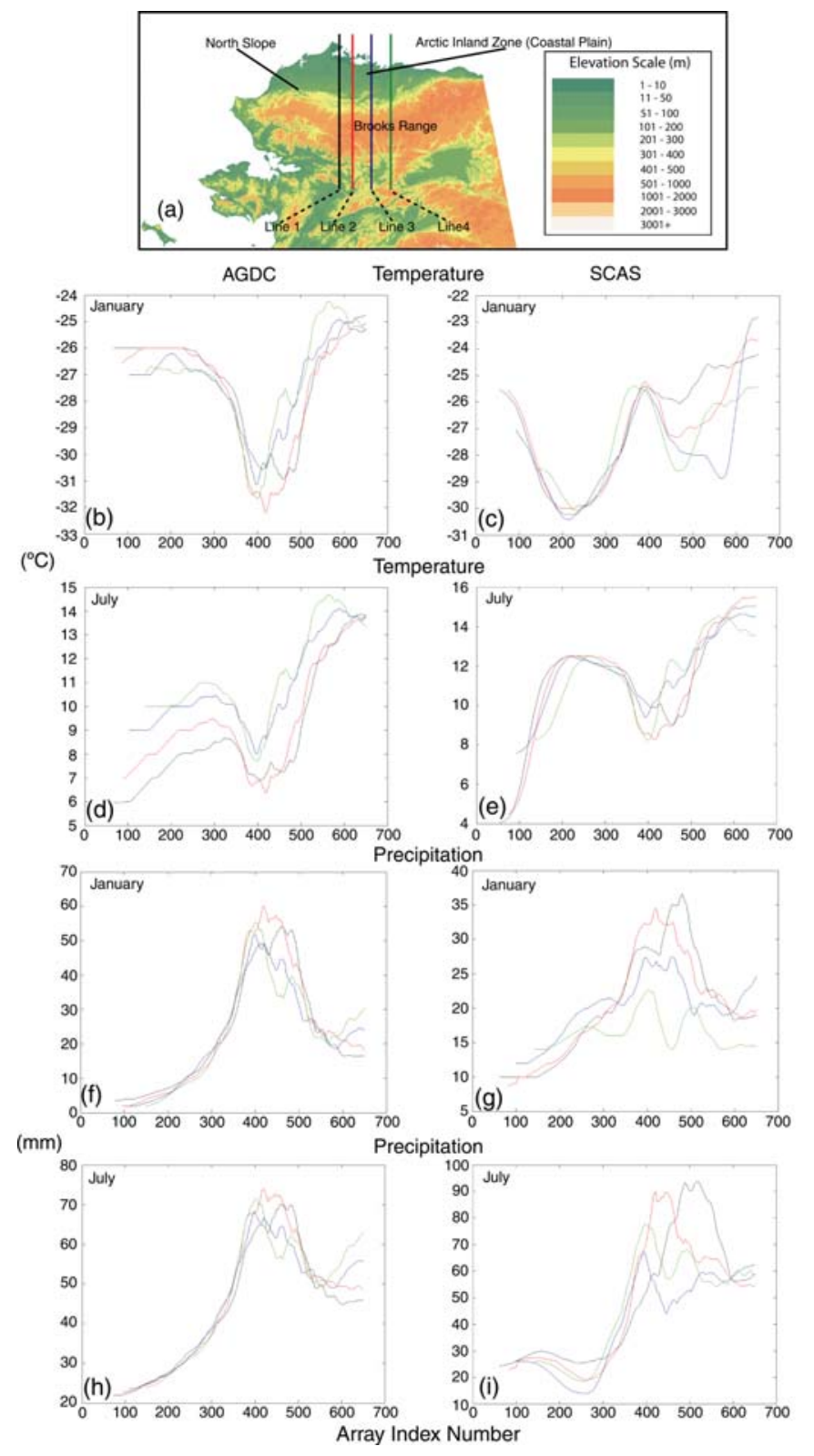

FIG. 17. a) Locations of the four transects used to sample the AGDC and SCAS data sets to construct shape functions. Panels $b-i$ are temperature or precipitation shape functions for either the AGDC or the SCAS data, as indicated. The $\mathrm{x}$-axis is an integer array index value. The first value shown in a given curve corresponds to a value at the coast. Each panel has its own vertical axis because of range differences between variables and data sets. See text for details.

1. Variability in surface temperature and precipitation is not uniform throughout Alaska. Therefore, we believe that a uniformly spaced observing grid is inappropriate.

2. The regions of largest uncertainty in Alaskan climate variables are in some of the most remote places in Alaska (e.g., the Brooks Range, the North Slope, the Wrangell-St. Elias Mountains, portions of interior Alaska and adjacent areas of Canada, and the Aleutian Islands). An upgrade of the Alaskan surface observation network should emphasize the instrumentation (with satellite telemetry capability) of such remote and totally undersampled areas.
3. In locating new observing stations, attention should be given to the vast upland areas of the Alaskan interior. In winter, the interior atmosphere is often decoupled vertically by persistent inversions. It is possible that largescale atmospheric variations such as ENSO and PDO will affect low-lying areas within the inversion layer very differently than it will affect upland areas in the free atmosphere above this layer. Currently, observational data represent low-lying areas almost exclusively.

4. Precipitation gauges in Alaska should be shielded to minimize undercatch.

5. Liquid and solid precipitation should be measured separately, using instrumentation specifically designed for each phase state.

6. Partnerships among various agencies are needed to properly implement an improved observational network for Alaska.

7. A common set of climate-quality instruments, calibration, analyses, and reporting procedures (e.g., common metadata standards, electronic delivery) also should be adopted.

8. Calibration transfer functions should be developed to facilitate the accurate construction of long-term climate-quality records as instruments change over time.

9. If possible, calibration transfer functions should be developed for historical data so that the climate record can be extended backwards in time with confidence.

\section{Applications to Other Areas of the Arctic}

Several factors complicate the construction of accurate climate-quality maps of Arctic surface temperature and precipitation. The observing network is sparse, the environment is harsh, and many of the instruments are unattended for long periods of time. Arctic solid precipitation is especially difficult to measure accurately because solid precipitation generally occurs during windy conditions, and precipitation gauges located in windy environments characteristically underestimate solid precipitation by significant amounts (e.g., Goodison et al., 1981). The annual range of surface temperature can be extreme (location dependent), which impacts the choice of appropriate instrumentation. Moreover, most instruments are located at relatively low elevations. Changes in instrumentation (e.g., different principles of measurement, intercalibration issues), while common to all station data, further exacerbate the intrinsic difficulties associated with observations in the Arctic. Correction of station data prior to model interpolation and mapping to a common grid is critically important.

The interpolation model to implement the mapping must be selected with care. Factors to consider include, but are not limited to, the density of stations available for input to the interpolation model and the layered structure of the interpolation model. The wintertime prevalence of atmospheric temperature inversions in the Arctic, for example, necessitates use of an interpolation model that can account for the 
inversions; otherwise, mapped mountain temperatures will be colder than appropriate. Likewise, the interpolation model should recognize and correct misleading precipitation-elevation relationships produced by sparse data, incorporate prevailing and often seasonably-dependent changes in storm tracks, and accommodate the effects of proximity to large water bodies on the mapped variables.

\section{CONCLUSIONS}

We have determined the similarities and differences between long-term mean monthly maps of surface temperature and precipitation for Alaska and adjacent areas of Canada produced by Oregon State University's Spatial Climate Analysis Service (SCAS) and the Alaska Geopotential Data Clearinghouse (AGDC) groups and given possible reasons for the differences observed. On the largest space scales, both sets of maps show that Alaska is divided into an interior zone (with a small coastal extension in south-central Alaska) with consistent seasonal differences (extremes in temperature; moderate variation in precipitation) that contrast with the consistent seasonal differences of the coastal domain (moderate variation in temperature, extremes in precipitation). The boundary between these zones is a region of maximum interannual variability (little year-to-year consistency in temperature and precipitation) but low mean long-term variability. Regions of maximum differences between the AGDC and the SCAS surface temperature and precipitation maps were identified; they reflect differences in regional-scale physiographic domains and in how the two groups treated these regions during their respective mapping programs. At least four factors contribute to these differences: 1) lack of instrumentation in many remote regions of Alaska; 2) differences in the data sets input to the PRISM (used by the SCAS group) and the ANUSPLIN (used by the AGDC group) models; 3 ) differences in the PRISM and ANUSPLIN models; and 4) differences in the end-to-end process used by the two groups to produce their respective Alaskan data sets. We conclude that the SCAS data set currently provides the best available spatial coverage of Alaskan surface temperature and precipitation, a conclusion supported by independent station-validation data for a topographically complex region of Alaska (Arctic Ocean to Brooks Range).

\section{ACKNOWLEDGEMENTS}

This work was supported by a NASA Pathfinder Project and a NASA ESIP project. Special thanks to J. Dodge and M. Maiden, NASA Program Managers. James Biskey, Ben Tsou, Michael Stuart, and L.J. Miller assisted with manuscript preparation. The helpful suggestions of the three anonymous reviewers are greatly appreciated.

\section{REFERENCES}

BENNING, J.L., DAQING, Y., and KANE, D.L. 2002. Adjustment of daily precipitation data at Barrow Alaska for 1995-2000 (Poster presentation abstract). In: Overpeck, J., ed. ARCSS AllHands Workshop: Proceedings of a workshop held 20 February 2002 at the Bell Harbor International Conference Center, Seattle, Washington. 62.

BRANTON, C.I., and WATSON, C.E. 1969. Precipitation probabilities for selected sites in Alaska. Technical Bulletin No. 1. Fairbanks: Agricultural Experiment Station, University of Alaska.

CRAMER, W., and LEEMANS, R. 1993. Assessing impacts of climate change on vegetation using climate classification systems. In: Solomon, A.M., and Shugart, H.H., eds. Vegetation dynamics and global change. New York: Chapman and Hill. 190-217.

DALY, C., NEILSON, R.P., and PHILIPS, D.L. 1994. A statisticaltopographic model for mapping climatological precipitation over mountainous terrain. Journal of Applied Meteorology 33:140-158.

DALY, C., TAYLOR, G.H., GIBSON, W.P., PARZYBOK, T.W., JOHNSON, G.L., and PASTERIS, P. 2001. High-quality spatial climate data sets for the United States and beyond. Transactions of the American Society of Agricultural Engineers 43: $1957-1962$.

DALY, C., GIBSON, W.P., TAYLOR, G.H., JOHNSON, G.L., and PASTERIS, P. 2002. A knowledge-based approach to the statistical mapping of climate. Climate Research 22:99-113.

DALY, C., HELMER, E.H., and QUINONES, M. 2003. Mapping the climate of Puerto Rico, Vieques and Culebra. International Journal of Climatology 23:1359-1381.

FLEMING, M.D. 1997. A statewide vegetation map of Alaska using phenological classification of AVHRR Data. In: Walker, D.A., and Lillie, A.C., eds. The Second Circumpolar Arctic Vegetation Mapping Workshop, 18-24 May 1996, Arendal, Norway and the CAVM-North American Workshop, 14-16 January 1997, Anchorage, Alaska. Occasional Paper No. 52. Boulder, Colorado: Institute of Arctic and Alpine Research. $25-26$.

- - - 2000. Metadata for a statewide vegetation map of Alaska. Anchorage: USGS EROS Data Center. ftp://agdcftp1.wr.usgs. gov/pub/projects/fhm/vegcls.txt.

FLEMING, M.D., CHAPIN, F.S., CRAMER, W., HUFFORD, G.L., and SERREZE, M.C. 2000. Geographic patterns and dynamics of Alaskan climate interpolated from a sparse station record. Global Change Biology 6(1):49-58.

GIBSON, W.P., DALY, C., and TAYLOR, G.H. 1997. Derivation of facet grids for use with the PRISM model. Proceedings of the 10th American Meteorological Society Conference on Applied Climatology, 20-24 October 1997, Reno, Nevada. 2-3.

GILL, P.E., MURRAY, W., and WRIGHT, M.H. 1991. Numerical linear algebra and optimization. New York: Addison-Wesley.

GOODISON, B.E., FERGUSON, H.L., and McKAY, G.A. 1981. Measurement and data analysis. In: Gray, D.M., and Male, D.H., eds. Handbook of snow: Principles, processes, management \& use. Toronto: Pergamon Press. 191-274. 
HOURSTON, R.A.S. 1998. A 1961-90 climatological data set for southern British Colombia. Prepared for Environment Canada, Climate Section, Aquatic and Atmospheric Sciences Division by WeatherWorks Consulting, Victoria, B.C. Available from Environment Canada, Inquiry Centre, 70 Crémazie St., Gatineau, Quebec K1A 0H3. 37 p.

HULME, M. 1995. Estimating global change in precipitation. Weather 50:34-42.

HUTCHINSON, H.F. 1995. Interpolating mean rainfall using thin plate smoothing splines. International Journal of Geographical Information Systems 9:385-403.

IPCC (INTERGOVERNMENTAL PANEL ON CLIMATE CHANGE). 1996. Climate change 1995: The science of climate change. Edited by J.T. Houghton, L.G. Meira Filho, B.A. Callander, N. Harris, A. Kattenberg, and K. Maskell, Cambridge: Cambridge University Press. 572 p.

JIA, G.J., EPSTEIN, H.E., and WALKER, D.A. 2003. Greening of Arctic Alaska, 1981-2001. Geophysical Research Letters 30:2067. doi: 10. 1029 / 2003 GLO18268.

JOHNSON, L.W., and RIESS, R.D. 1982. Numerical analysis. 2nd ed. Reading, Massachusetts: Addison-Wesley.

KÅLLBERG, P., SIMMONS, A., UPPALA, S., and FUENTES, M. 2004. The ERA-40 archive. ECMWF ERA-40 Project Report Series 17. Shinfield Park, Reading: European Centre for MediumRange Weather Forecasts.

KARL, T.R., GROISMAN, P., KNIGHT, R.W., and HEIM, R.R., Jr. 1993. Recent variations in snowcover and snowfall in North America and their relation to precipitation and temperature variations. Journal of Climate 6:1327-1344.

KILDAY, G.D. 1974. Mean monthly and annual precipitation Alaska. NOAA technical memorandum NWS AR-10. Washington D.C.: Department of Commerce.

KOZO, T.L. 1982. An observational study of sea breeze along the Alaskan Beaufort Sea coast: Part I. Journal of Applied Meteorology 21:891-905.

LARSON, L.W., and PECK, E.L. 1974. Accuracy of precipitation measurements for hydrologic modeling. Water Resource Research 10:857-863.

LEGATES, D.R., and WILMOT, C.J. 1990. Mean seasonal and spatial variability in gauge-corrected, global precipitation. International Journal of Climatology 10:111-128.

NORTH, G.R., BELL, T.L., CAHOLAN, R.F., and MOENG, F. 1982. Sampling errors in the estimation of empirical orthogonal functions. Monthly Weather Review 110:699-706.

PREISENDORFER, R.W. 1988. Principal component analysis in meteorology and oceanography. Amsterdam: Elsevier.

RICHMAN, M.B. 1986. Obliquely rotated principal components. Journal of Climatology 6:293-335.
SEVRUK, B. 1982. Methods of correction for systematic error in point precipitation measurement for operational use. Operational Hydrology Report No. 21, WMO No. 589. Geneva: World Meteorological Organization.

SIMPSON, J.J., HUFFORD, G.L., FLEMING, M., BERG, J.S., and ASHTON, J.B. 2002. Long-term climate patterns in Alaskan surface temperature and precipitation and their biological consequences. IEEE Transactions on Geosciences and Remote Sensing 40:1164-1184.

USDA-NRCS (UNITED STATES DEPARTMENT OF AGRICULTURE-NATURAL RESOURCES CONSERVATION SERVICE). 1998. PRISM Climate Mapping Project Precipitation. Mean monthly and annual precipitation digital files for the continental U.S. Ft. Worth, Texas: USDA-NRCS National Cartography and Geospatial Center. CD-ROM.

VOSE, R.S., SCHMAYER, R.L., STEURER, P.M., PETERSON, T.C., HEIM, R., KARL, T.R., and EISCHEID, J. 1992. The global historical climate network: Long-term monthly temperature, precipitation, sea level pressure, and station pressure data. ORNL/CDIAC-53, NDP-041. Oak Ridge, Tennessee: Carbon Dioxide Information Analysis Center, Oak Ridge National Laboratory.

WAHBA, G. 1979. How to smooth curves and surfaces with spline and cross-validation. In: 24th Design of Experiments Conference. Proceedings of a conference held 3-4 May 1978, Madison, Wisconsin. Research Triangle Park, North Carolina: U.S. Army Research Office. 167-192.

WALSH, J.E., KATTSOV, V., PORTIS, D., and MELESHKO, V. 1998. Arctic precipitation and evaporation: Model results and observational estimates. Journal of Climate 11:72-87.

WENDLER, G., ISHIKAWA, N., and STRETEN, N. 1974. The climate of McCall Glacier, Brooks Range, Alaska, in relation to its geographical setting. Arctic and Alpine Research 6: $307-318$.

YANG, D., GOODISON, B.E., METCALFE, J.R., GOLUBEV, U.S., BATES, R., PANGBURN, T., and HANSON, C.L. 1998. Accuracy of NWS 8 standard nonrecording precipitation gauge: Results and application of WMO intercomparison. Journal of Atmospheric and Oceanic Technology 15:54-68.

YANG, D., KANE, D.L., HINZMAN, L.D., GOODISON, B.E., METCALFE, J.R., LOUIE, P.Y.T., LEAVESLEY, D.H., EMERSON, D.G., and HANSON, C.L. 2000. An evaluation of the Wyoming gauge system for snowfall measurement. Water Resources Research 36(9):2665-2678.

ZHANG, T., OSTERKAMP, T.E., and STAMMES, K. 1996. Some characteristics of the climate in northern Alaska, U.S.A. Arctic and Alpine Research 28:509-518. 